\title{
Studies on the Interaction between Poly-Phosphane Gold(I) Complexes and Dihydrofolate Reductase: An Interplay with Nicotinamide Adenine Dinucleotide Cofactor
}

\author{
Stefania Pucciarelli ${ }^{1}\left(\mathbb{D}\right.$, Silvia Vincenzetti $^{1}{ }^{\mathbb{D}}$, Massimo Ricciutelli ${ }^{2}$, Oumarou Camille Simon ${ }^{2}$, \\ Anna Teresa Ramadori ${ }^{2}$, Lorenzo Luciani ${ }^{2}$ and Rossana Galassi ${ }^{2}$ * (D) \\ 1 School of Biosciences and Veterinary Medicine, University of Camerino, Via Gentile III da Varano, \\ 62032 Camerino, Italy; stefania.pucciarelli@unicam.it (S.P.); silvia.vincenzetti@unicam.it (S.V.) \\ 2 School of Science and Technology, University of Camerino, Via Sant'Agostino, 1, 62032 Camerino, Italy; \\ massimo.ricciutelli@unicam.it (M.R.); camilleoumarou@yahoo.fr (O.C.S.); \\ annateresa.ramadori@unicam.it (A.T.R.); lorenzo.luciani@unicam.it (L.L.) \\ * Correspondence: rossana.galassi@unicam.it
}

Received: 18 March 2019; Accepted: 9 April 2019; Published: 11 April 2019

\begin{abstract}
A class of gold(I) phosphane complexes have been identified as inhibitors of dihydrofolate reductase (DHFR) from E. coli, an enzyme that catalyzes the reduction of dihydrofolate (DHF) to tetrahydrofolate (THF), using NADPH as a coenzyme. In this work, to comprehend the nature of the interaction at the basis of these inhibitory effects, the binding properties of bis- and tris-phosphane gold(I) chloride compounds in regards to DHFR have been studied by emission spectroscopy and spectrophotometric assays. The lack of cysteine and seleno-cysteine residues in the enzyme active site, the most favorable sites of attack of $\mathrm{Au}(\mathrm{I})$ moieties, makes this work noteworthy. The interaction with the gold compounds results into the quenching of the DHFR tryptophan's emissions and in an enhancement of their intrinsic emission intensities. Moreover, a modulating action of NADPH is highlighted by means of an increase of the gold compound affinity toward the enzyme; in fact, the dissociation constants calculated for the interactions between DHFR and each gold compound in the presence of saturating NADPH were lower than the ones observed for the apo-enzyme. The fluorimetric data afforded to $\mathrm{K}_{\mathrm{d}}$ values ranged from $2.22 \pm 0.25 \mu \mathrm{M}$ for $\left(\mathrm{PPh}_{3}\right)_{2} \mathrm{AuCl}$ in the presence of NADPH to $21.4 \pm 3.85 \mu \mathrm{M}$ for ${ }^{4} \mathrm{~L}_{3} \mathrm{AuTf}$ in the absence of NADPH. By elucidating the energetic aspects of the binding events, we have attempted to dissect the role played by the gold phosphane/protein interactions in the inhibitory activity, resulting in an exothermic enthalpy change and a positive entropic contribution $\left(\Delta \mathrm{H}^{\circ}=-5.04 \pm 0.08 \mathrm{kcal} / \mathrm{mol}\right.$ and $\left.\Delta \mathrm{S}^{\circ}=7.34 \pm 0.005 \mathrm{cal} / \mathrm{mol} \cdot \mathrm{K}\right)$.
\end{abstract}

Keywords: protein-metal adducts; enzyme inhibition; DHFR; gold(I) phosphane compounds; thermodynamic data; enzymatic assays

\section{Introduction}

Dihydrofolate reductase (DHFR) is a ubiquitous enzyme responsible for maintaining a pool of tetrahydrofolate (labelled as THF or H4F) in cells. THF is an active form of the vitamin folic acid and the precursor for purines, pyrimidines, and several amino acids necessary for synthesis in cells and for their growth [1]. In particular, DHFR catalyzes the reduction of 7,8-dihydrofolate (labelled as DHF or H2F) to THF by stereospecific hydride transfer from the NADPH cofactor (Nicotinamide Adenine Dinucleotide Phosphate) to the $\mathrm{C} 6$ atom of the pterin ring, with concomitant protonation at 
N5 (Scheme 1) [2]. This catalytic role makes DHFR a therapeutic target by chemical and genetic means, having the scope to hamper the proliferation and the growth of cells $[3,4]$.<smiles>[R2]NCC1=Nc2c(nc(N)[nH]c2=O)NC1CCCCCCC1C=CN([R1])C=C1C(N)=O</smiles>

dihydrofolate $(\mathrm{H} 2 \mathrm{~F})$

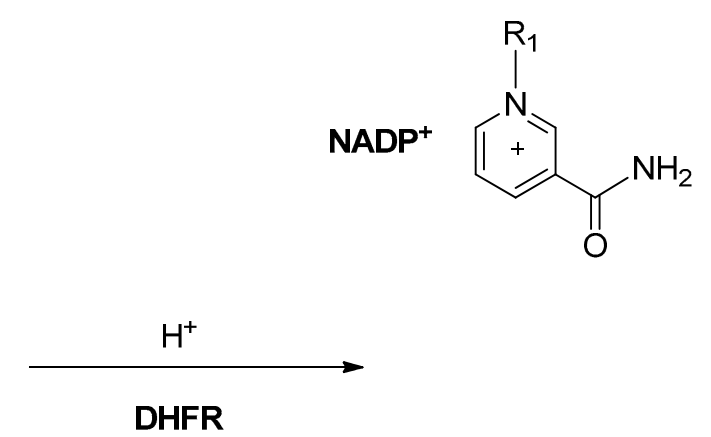<smiles>[R2]NC[C@H]1CNc2nc(N)[nH]c(=O)c2N1</smiles>

Scheme 1. Schematic representation of the reduction reaction catalyzed by dihydrofolate reductase (DHFR).

Classic antimicrobial DHFR inhibitors [5] are TMP (trimetoprin) and its analogs [4,6]; their action is mainly based on the competition with the pteridine moiety of DHF. Methotrexate is the DHFR inhibitor used most often in a clinical setting as an anticancer drug, and as an anti-inflammatory and immunosuppressive agent. Methotrexate (MTX) acts through a $10^{3}$ stronger bond to DHFR than to DHF itself $[7,8]$. The antifolate treatments may afford eventual resistance, which is one of the most important serious side effects observed, resulting in a complete loss of efficacy $[9,10]$. Then, the identification of new entities possessing the skill to inhibit DHFR becomes a challenging issue, as well as the study of the mechanism developing the drug resistance [11,12]. Whilst this latter aspect has been approached, the research of innovative antifolate compounds has been neglected. The design of antifolate compounds was mainly led by considering structural DHF analogies [11], and few alternative molecules have been tested as DHFR inhibitors [12]. In recent research, gold(I) azolate/phosphane compounds (where the phosphane was $\mathrm{PPh}_{3}$, and the azolate were some 3,5-di-substituted pyrazoles and 4,5-di-substituted imidazoles) were found to be cytotoxic in vitro against many panels of cancer cells, and two of them were found to be strongly active also in vivo on the treatment of BBLC sick syngeneic mice. They were found to possess mechanisms of action that were strongly dependent on their structure. In this regard, some years ago, our group was involved in a pioneer study where, surprisingly, these phosphane gold(I) compounds $[13,14]$ and their relative bis-phosphane gold(I) compounds were found to inhibit DHFR from E. coli in the micromolar range of concentration [15]. This latter work was done with the double goal to contribute to the shared hypothesis that bioactive anticancer or antimicrobial gold(I) phosphane compounds interact with different enzymes, depending on (even mild) structural modifications [16,17], and with the aim to find new inhibitors of DHFR. Previously [15], mono- or bis- phosphane gold(I) compounds were tested as DHFR inhibitor; nevertheless, a structure activity relationship (SAR) was difficult to be discussed for mono- and bis- phosphane gold(I) compounds and some anomalies on the Ki's values solicited a further study in depth. In order to accomplish this deepening, some gold(I) phosphane compounds were reconsidered and additional phosphane gold(I) compounds were synthesized to evaluate the nature of the DHFR/NADPH/gold compounds interactions. Exploiting the emissive properties of the tryptophan groups in DHFR, spectrofluorimetric and UV-visible spectroscopy assays [18-20] were performed to obtain kinetic and thermodynamic data for the DHFR/gold phosphane compounds adducts. For this purpose, $\mathrm{PPh}_{3}(\mathrm{~L})$ and analogs containing 
the $\mathrm{COOH}$ in ortho $\left({ }^{2} \mathrm{~L}\right) /$ para $\left({ }^{4} \mathrm{~L}\right)$ position, or the $\mathrm{COOCH}_{3}\left({ }^{4 \mathrm{Me}} \mathrm{L}\right)$ in para position of the phosphane ligand, were used to synthesize mononuclear bis- and tris-phosphane gold(I) compounds.

\section{Results and Discussion}

\subsection{Gold(I) Compounds Preparation}

For this work, the synthesis of a selection of gold(I) poly-phosphane complexes was planned to understand some aspects of the structural/activity/relationship of these gold compounds. Specifically, (a) the change of the inhibitory activity as a function of the number of phosphane ligands around the metal center, (b) the effect of a carboxylic group in the phosphane ligand on the mechanism of interaction with the enzyme, (c) the putative role of the chloride ion in the activity of the gold complex, and (d) the binding, if indeed it occurs, between the $\mathrm{OH}$ of the carboxylic group and the DHFR in the interaction event. The synthesis of bis- and tris-phosphane gold(I) complexes with $\mathrm{PPh}_{3}$ has already been discussed in literature and it represents the inspiration for the preparation of ${ }^{4} \mathrm{~L}$ or ${ }^{2} \mathrm{~L}$ gold complexes [21]. The syntheses proceed according to the substitution of the labile $\left(\mathrm{Me}_{2} \mathrm{~S}\right)$ by direct addition of the phosphane ligands to [ $\left.\mathrm{AuCl}\left(\mathrm{Me}_{2} \mathrm{~S}\right)\right]$ in a mole ratio 4:1, respectively; the excess of the phosphane ligand guarantees the shift of the equilibrium reaction toward the product, which is then isolated as a solid and characterized by elemental analysis, IR spectroscopy in the solid state, and ${ }^{1} \mathrm{H},{ }^{31} \mathrm{P}$ NMR, UV-visible, spectrofluorimetric spectroscopies, and ESI Mass Spectrometry in solution (Electro Spray Ionization Mass Spectrometry). The presence of a deactivating group, such as the carboxylic in para or ortho position of one phenyl group, confers less $\sigma$-donor skill to the phosphane ligands, labelled as ${ }^{4} \mathrm{~L}$ or ${ }^{2} \mathrm{~L}$, yielding to quite stable gold complexes with higher coordination numbers around the gold center. The synthesis of the compound ${ }^{4} \mathrm{~L}_{3} \mathrm{AuTfl}(\mathrm{Tfl}=$ triflate) was performed according to the direct reaction of the ligand, ${ }^{4} \mathrm{~L}$, with the $\left[\mathrm{AuTfl}\left(\mathrm{Me}_{2} \mathrm{~S}\right)\right]$ in the mole ratio 4:1; this method was preferred to the direct methatesis between ${ }^{4} \mathrm{~L}_{3} \mathrm{AuCl}$ and AgTfl. The analysis of the ${ }^{4} \mathrm{~L}_{3} \mathrm{AuTfl}$ complex highlights a likely role of the chloride ion in the stability of the gold complexes in solution which was already discussed for the $\mathrm{PPh}_{3}$ analogs [21]: if we compare the ${ }^{31} \mathrm{P}$ NMR chemical shift of ${ }^{4} \mathrm{~L}_{3} \mathrm{AuCl}$ and of ${ }^{4} \mathrm{~L}_{3} \mathrm{AuTfl}$, we observe a shift to lower frequencies (from 42.1 to $32.6 \mathrm{ppm}$ in $\mathrm{CH}_{3} \mathrm{OD}$, respectively) and the appearance of a signal at $22.6 \mathrm{ppm}$ for the latter (with an intensity of about 1:10 relative to the main product at $32.6 \mathrm{ppm}$ ). These data indicate the absence of the chloride markedly changes the electronic environment of the phosphorous center, and affords a likely dissociation to the monophosphane gold(I) compound; in fact, the ${ }^{31} \mathrm{P}$ NMR chemical shift of the tris- and bis-phosphane gold(I) complexes fall quite close to each other, which are 8-10 ppm higher frequencies with respect to the chemical shift of the $\mathrm{LAuCl}$ derivative [15]. Finally, the formation of the methyl ester on the ligand ${ }^{4} \mathrm{~L}$ and of the corresponding gold(I) complex, ${ }^{4{ }^{4 e}} \mathrm{~L}_{3} \mathrm{AuCl}$, had the scope to suppress the skill of the 4-benzoic-diphenylphoshane acid ligand to act as a hydrogen bonding donor in the interaction with DHFR.

\subsection{Inhibition Studies}

The phosphane gold(I) compounds were used to prepare buffered stock solutions at $\mathrm{pH}=7.3$ at $30^{\circ} \mathrm{C}$ for the inhibition tests of DHFR from E coli. In Table 1, the list of the gold(I) compounds used for the tests and the corresponding inhibition constants are reported. 
Table 1. List of the compounds tested and corresponding Ki values.

\begin{tabular}{|c|c|c|}
\hline Compound & Labels & $\mathbf{K i}(\mu \mathrm{M})$ \\
\hline$\left[(4-\mathrm{COOH} \mathrm{Ph}) \mathrm{Ph}_{2} \mathrm{P}\right]_{3} \mathrm{AuCl}$ & ${ }^{4} \mathrm{~L}_{3} \mathrm{AuCl}$ & $4.6 \pm 0.5$ \\
\hline$\left[(4-\mathrm{COOH} \mathrm{Ph}) \mathrm{Ph}_{2} \mathrm{P}\right]_{3} \mathrm{AuTfl}$ & ${ }^{4} \mathrm{~L}_{3} \mathrm{AuTfl}$ & $6.33 \pm 0.7$ \\
\hline$\left[(4-\mathrm{MeO}-\mathrm{Ph}) \mathrm{Ph}_{2} \mathrm{P}\right]_{3} \mathrm{AuCl}$ & ${ }^{4 \mathrm{Me}_{\mathrm{L}} \mathrm{AuCl}}$ & $12.72 \pm 2.1$ \\
\hline$\left[(2-\mathrm{COOH} \mathrm{Ph}) \mathrm{Ph}_{2} \mathrm{P}\right]_{3} \mathrm{AuCl}$ & ${ }^{2} \mathrm{~L}_{3} \mathrm{AuCl}$ & $21.26 \pm 3.8$ \\
\hline$\left(4 \mathrm{COOHPh}-\mathrm{Ph}_{2} \mathrm{P}\right)_{2} \mathrm{AuCl}$ & ${ }^{4} \mathrm{~L}_{2} \mathrm{AuCl}$ & $27.84 \pm 12.12 *$ \\
\hline$\left(2 \mathrm{COOHPh}-\mathrm{Ph}_{2} \mathrm{P}\right)_{2} \mathrm{AuCl}$ & ${ }^{2} \mathrm{~L}_{2} \mathrm{AuCl}$ & $2.066 \pm 0.8 *$ \\
\hline$\left(\mathrm{PPh}_{3}\right)_{2} \mathrm{AuCl}$ & $\mathrm{L}_{2} \mathrm{AuCl}$ & $0.53 \pm 0.03$ \\
\hline$\left(4 \mathrm{COOHPh}-\mathrm{Ph}_{2} \mathrm{P}\right) \mathrm{AuCl}$ & ${ }^{4} \mathrm{LAuCl}$ & $2.25 \pm 0.62 *$ \\
\hline$\left(2 \mathrm{COOHPh}-\mathrm{Ph}_{2} \mathrm{P}\right) \mathrm{AuCl}$ & ${ }^{2} \mathrm{LAuCl}$ & $1.10 \pm 0.3^{*}$ \\
\hline $\mathrm{PPh}_{3} \mathrm{AuCl}$ & $\mathrm{LAuCl}$ & $1.214 \pm 0.20 *$ \\
\hline $\mathrm{PPh}_{3}$ & $\mathrm{~L}$ & $6.16 \pm 0.77^{*}$ \\
\hline $4 \mathrm{COOHPh}-\mathrm{Ph}_{2} \mathrm{P}$ & ${ }^{4} \mathrm{~L}$ & No inhibition * \\
\hline $2 \mathrm{COOHPh}-\mathrm{Ph}_{2} \mathrm{P}$ & ${ }^{2} \mathrm{~L}$ & No inhibition * \\
\hline
\end{tabular}

The inhibition action of the gold phosphane compounds was tested in regards to the reduction of $\mathrm{H} 2 \mathrm{~F}$ to H4F reaction, catalyzed by DHFR [2]. The inhibition tests were led by analyzing the reciprocal reaction rate upon the addition of Hepes/methanol solutions of gold compounds in different set of tests in the saturated concentration of NADPH. The tests were repeated with different amounts of dihydrofolate (DHF) $(1.5 \div 10 \mu \mathrm{M})$. Typical sets of tests are reported in Figure 1 .

(A)

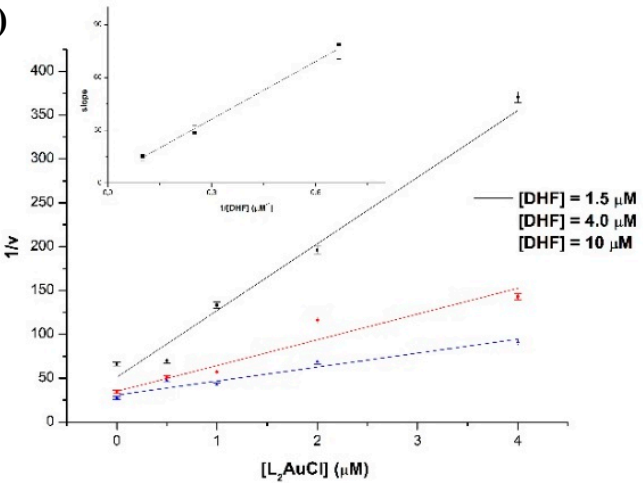

(B)

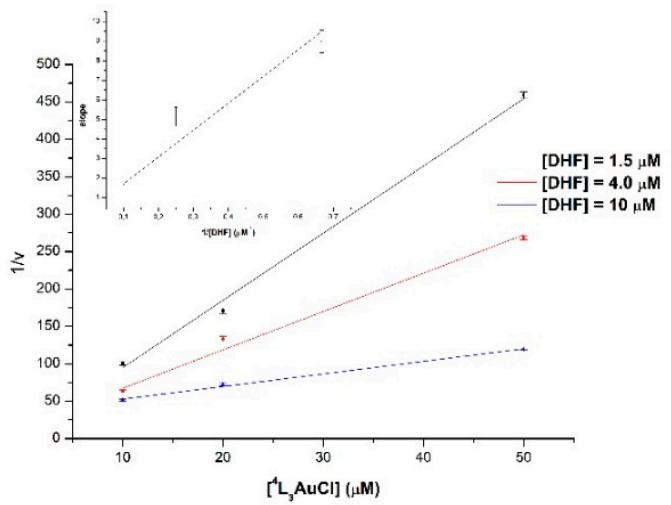

Figure 1. Dixon plot with the secondary plot in the inset for compound $\mathrm{L}_{2} \mathrm{AuCl}(\mathbf{A})$ and ${ }^{4} \mathrm{~L}_{3} \mathrm{AuCl}(\mathbf{B})$.

The data were processed according to a linear regression (Equation (1)) obtaining the values reported in Table 1. The standard deviations were calculated for a minimum of three determinations.

$$
\frac{1}{v}=\frac{K m}{V \max K i[S]} *[I]+\frac{1}{V \max }\left(1+\frac{K m}{[S]}\right)
$$

The analysis of the data shows that the most active inhibitor is the $\mathrm{L}_{2} \mathrm{AuCl}$ with a $\mathrm{Ki}=0.53 \mu \mathrm{M}$, followed by the $\mathrm{LAuCl}$ and other derivatives as shown in Table 1. Modification on the phosphane ligand with a reactive group, such as the carboxylic moiety, does not improve the inhibition power, which is further worsened by its conversion to the methyl ester derivative, [(4-MeO-Ph) $\mathrm{Ph}_{2} \mathrm{P}_{3} \mathrm{AuCl}$. Notably, for the tris-phosphane gold compounds, the substitution of the chloride with the triflate ion slightly worsens the inhibition property. The change of the position of $\mathrm{COOH}$ from para to ortho led to 
an increase of the Ki values. Remarkably, by comparing the gold complexes Ki values with those of the free ligands, the central role of the gold atom on the activation of the inhibition properties is visible.

\subsection{Fluorimetric Studies}

Before approaching the fluorimetric studies for the determination of the binding constants, the emissive properties of the phosphane gold(I) complexes in Hepes/methanol solutions were assessed. The fluorimetric data, both in the absence and in the presence of DHFR, are reported in Table 2. The emission spectra of compounds ${ }^{4} \mathrm{~L}_{3} \mathrm{AuCl},{ }^{4} \mathrm{~L}_{3} \mathrm{AuTfl},{ }^{4} \mathrm{~L}_{2} \mathrm{AuCl},{ }^{2} \mathrm{~L}_{3} \mathrm{AuCl},{ }^{2} \mathrm{~L}_{2} \mathrm{AuCl}$, and $\mathrm{L}_{2} \mathrm{AuCl}$ were recorded in $20 \mathrm{mM}$ Hepes $/ \mathrm{CH}_{3} \mathrm{OH}$ solutions with concentrations of the metal complexes ranging from 4 to $50 \mu \mathrm{M}$. The emission's spectra of the tested gold(I) phosphane complexes are shown in Figure 2. The most intense emissions show maxima at about 490 and $520 \mathrm{~nm}$. These values are close to those observed for the $\left(\mathrm{PPh}_{3}\right)_{3} \mathrm{AuCl}$ and can be attributed to the presence of different geometries around the gold center in solution [21]. The compound $\left(\mathrm{PPh}_{3}\right)_{2} \mathrm{AuCl}$, the emissive properties of which have been largely assessed in literature [21,22], is a good reference for the evaluation of the effect of the $\mathrm{COOH}$ group on the interaction with the enzyme. Most of the complexes showed intrinsic emissions in the yellow-green visible range by excitation at $280 \mathrm{~nm}$ (which corresponds to the typical absorbance of tryptophan's in the enzyme), with a strong dependency of the intensity upon the increase of the concentration of the gold(I) compound. The emissions of these solutions are not affected by the presence of oxygen; moreover, according to the large Stokes's shifts and the studies on halftimes reported in literature for similar $\left(\mathrm{PPh}_{3}\right)_{3} \mathrm{AuCl}$ compounds, a likely phosphorescence decay may be attributed to these emissions. The intensity resulted in greater strength for the tris-coordinate geometry rather than for the bis-coordinate compounds [21,23]. In these $\mathrm{PPh}_{3}$-related compounds, the nature of the emission was explained by a charge transfer from the metal to the ligand antibonding orbitals $\pi^{*}$ $\leftarrow \mathrm{d}$. Therefore, the introduction of the one $\mathrm{COOH}$ group slightly affects the emissive properties, and for the ester ligand derivative, ${ }^{4 \mathrm{Me}} \mathrm{L}_{3} \mathrm{AuCl}$, the most intense emission was observed [24].

Table 2. List of fluorescence data for the gold(I) compounds once treated with DHFR (DiHydroFolate Reductase) and DHFR/NADPH (Nicotinamide Adenine Dinucleotide Phosphate), with the corresponding Kd values.

\begin{tabular}{|c|c|c|c|c|}
\hline Compound & $\begin{array}{c}\text { Intrinsic Emission } \lambda_{\text {em }} \\
\left(\lambda_{\text {exc }}=280 \mathrm{~nm}\right) \\
\text { Hepes/methanol }\end{array}$ & Stokes Shift & $\begin{array}{c}\mathrm{Kd} \pm \text { s.d. }{ }^{*}, T=25^{\circ} \mathrm{C}(\mu \mathrm{M}) ; n \\
=\text { Hill Coefficient }\end{array}$ & $\begin{array}{c}\text { Kd } \pm \text { s.d. } *\left(25^{\circ} \mathrm{C}\right)(\mu \mathrm{M}) \\
\text { In Presence of } \\
\text { Saturating NADPH }\end{array}$ \\
\hline${ }^{4} \mathrm{~L}_{3} \mathrm{AuCl}$ & 520 and $485 \mathrm{~nm}$ & $\begin{array}{l}16,483 \text { and } 15,095 \\
\mathrm{~cm}^{-1}\end{array}$ & $\begin{array}{c}3.84 \pm 0.29 ; n=1.73 ; 3.32 \pm \\
1.28\left(10{ }^{\circ} \mathrm{C}\right) ; 2.0 \pm 0.36\left(-4{ }^{\circ} \mathrm{C}\right)\end{array}$ & $5.05 \pm 2.7$ \\
\hline${ }^{4} \mathrm{~L}_{3} \mathrm{AuTfl}$ & $510 \mathrm{~nm}$ weak & $16,106 \mathrm{~cm}^{-1}$ & $\begin{array}{c}21.4 \pm 3.85 ; 7.36 \pm 0.84\left(10^{\circ} \mathrm{C}\right) \\
8.08 \pm 1.00\left(-4^{\circ} \mathrm{C}\right)\end{array}$ & $7.36 \pm 0.84$ \\
\hline${ }^{4 \mathrm{Me}} \mathrm{L}_{3} \mathrm{AuCl}$ & 517 and $500 \mathrm{~nm}$ & $\begin{array}{l}16,371 \text { and } 15,714 \\
\mathrm{~cm}^{-1}\end{array}$ & $\begin{array}{c}13.4 \pm 2.24 ; 7.63 \pm 0.93\left(10^{\circ} \mathrm{C}\right) \\
21.2 \pm 1.83\left(-4{ }^{\circ} \mathrm{C}\right)\end{array}$ & $4.55 \pm 1.04$ \\
\hline${ }^{4} \mathrm{~L}_{2} \mathrm{AuCl}$ & No intrinsic emission & n. d. & $\begin{array}{c}4.42 \pm 0.56 ; 3.52 \pm 0.15\left(10^{\circ} \mathrm{C}\right) \\
3.06 \pm 0.87\left(-4{ }^{\circ} \mathrm{C}\right)\end{array}$ & $2.35 \pm 0.61$ \\
\hline${ }^{2} \mathrm{~L}_{3} \mathrm{AuCl}$ & No intrinsic emission & n. d. & $\begin{array}{c}10.47 \pm 1.074 ; n=1.23 \pm 0.082 \\
7.12 \pm 0.22\left(10^{\circ} \mathrm{C}\right) ; n=1.41 \pm \\
0.048 ; 5.11 \pm 4.2\left(-4{ }^{\circ} \mathrm{C}\right)\end{array}$ & $7.32 \pm 2.46$ \\
\hline${ }^{2} \mathrm{~L}_{2} \mathrm{AuCl}$ & No intrinsic emission & n. d. & $10.33 \pm 0.65$ & $4.73 \pm 0.68$ \\
\hline$\left(\mathrm{PPh}_{3}\right)_{2} \mathrm{AuCl}$ & 521 and $490 \mathrm{~nm}$ & $\begin{array}{l}16,520 \text { and } 15,306 \\
\mathrm{~cm}^{-1}\end{array}$ & $\begin{array}{c}5.99 \pm 0.40 ; 2.47 \pm 0.29\left(10^{\circ} \mathrm{C}\right) \\
3.83 \pm 1.85\left(-4{ }^{\circ} \mathrm{C}\right)\end{array}$ & $2.22 \pm 0.25$ \\
\hline $4 \mathrm{COOHPh}_{2} \mathrm{P}$ & N.A. & n. d. & $59.6 \pm 5.7$ & N.A. \\
\hline Benzoic acid & N.A. & n. d. & $\approx 4000$ & N.A. \\
\hline
\end{tabular}




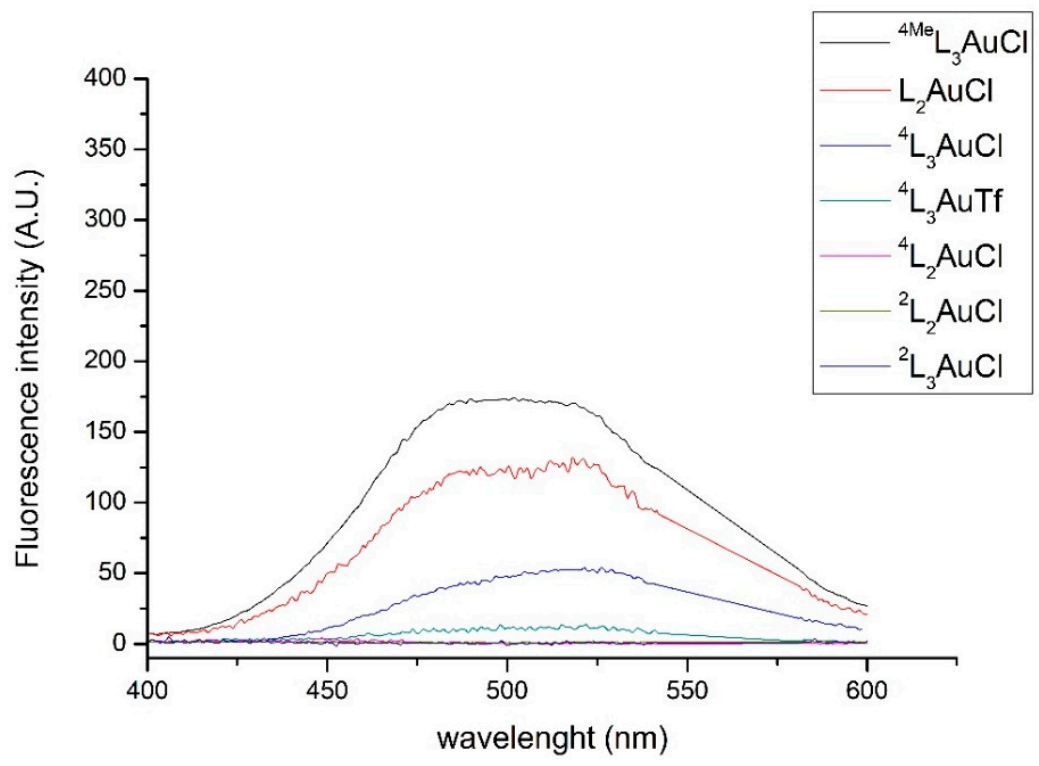

Figure 2. Emission spectra recorded in Hepes/methanol $22.86 \mu \mathrm{M}$ solutions of polyphosphane gold(I) chloride compounds $\left(\lambda_{\text {exc }}=280 \mathrm{~nm}\right)$. Compounds ${ }^{4} \mathrm{~L}_{2} \mathrm{AuCl},{ }^{2} \mathrm{~L}_{2} \mathrm{AuCl}$, and ${ }^{2} \mathrm{~L}_{3} \mathrm{AuCl}$ show weak intrinsic emissions and their spectra falls in the baseline intensity.

\subsection{Enzyme Binding Studies by Fluorimetric Assays}

The Hepes/methanol solutions of the gold(I) compounds were used for the fluorimetric assays (see materials and methods section) regarding DHFR from E. coli. The emission's maximum of DHFR was detected at $344 \mathrm{~nm}$ upon excitation at $280 \mathrm{~nm}$; by adding additional amounts of the gold complex in Hepes/methanol solutions (ranging among $4 \div 50 \mu \mathrm{M}$ ), the quenching of this emission intensity was observed. In Figure 3, spectra showing the effect of ${ }^{4} \mathrm{~L}_{3} \mathrm{AuCl}$ on DHFR emission are reported. It is possible to observe the quenching of the Tryptophan's emission and the corresponding increase of the intrinsic phosphorescence of the gold compound.

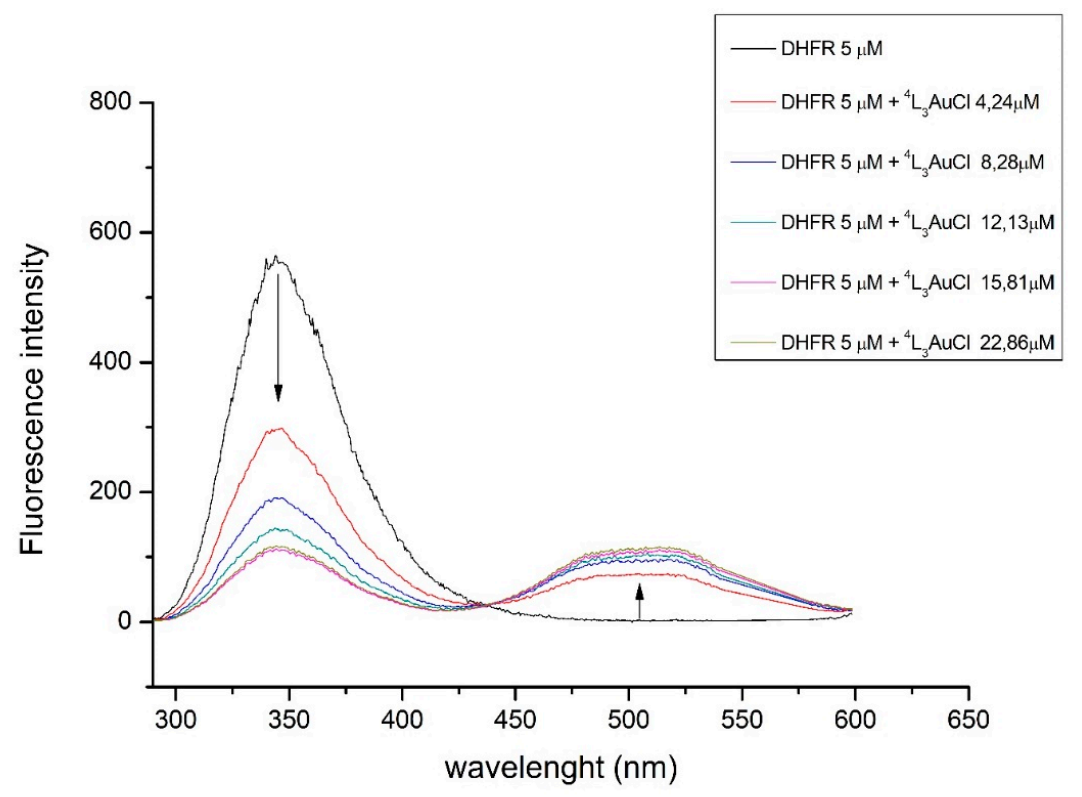

Figure 3. Emission spectra recorded for DHFR upon adding increasing concentration of ${ }^{4} \mathrm{~L}_{3} \mathrm{AuCl}\left(\lambda_{\text {exc }}\right.$ $=280 \mathrm{~nm}$ ). In the inset legend, the color corresponds to the curve and the respective concentrations. The spectra show the quenching of the DHFR's tryptophan emission upon the addition of the gold compound and the concomitant increase of the emission's intensity, attributed to the gold compound. 
The hyperchromic effect is visible in Figure 4, where the overlaid spectra obtained for the ${ }^{4} \mathrm{~L}_{3} \mathrm{AuCl}$ in the presence and in the absence of DHFR are reported.

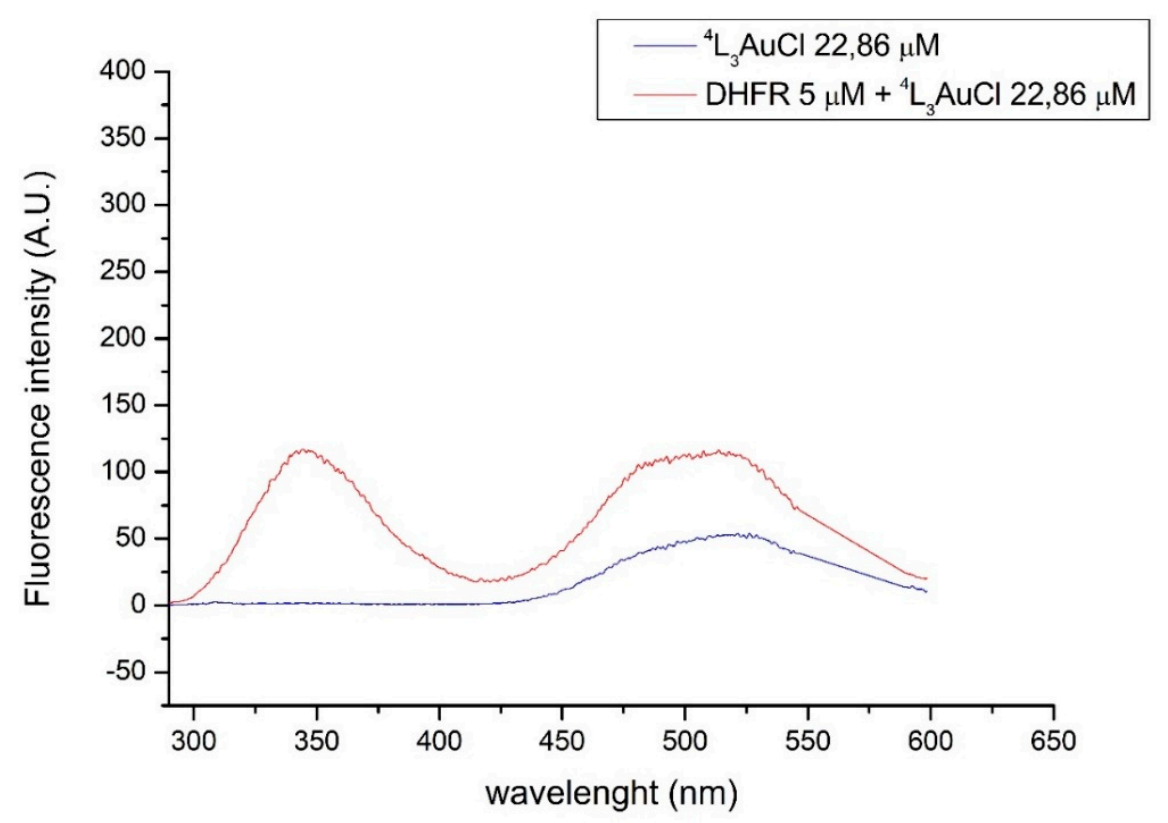

Figure 4. Comparison of the emission curves recorded for the intrinsic emission of ${ }^{4} \mathrm{~L}_{3} \mathrm{AuCl}$ in Hepes/methanol solution in the absence and in the presence of DHFR $\left({ }^{4} \mathrm{~L}_{3} \mathrm{AuCl} 22.86 \mu \mathrm{M}\right.$ in both spectra, $\left.\lambda_{\text {exc }}=280 \mathrm{~nm}\right)$.

The analysis of the emission's quenching data was processed according to methods discussed in the materials and methods section. Upon treatment of DHFR with ${ }^{4} \mathrm{~L}_{3} \mathrm{AuCl}$, the $\mathrm{K}_{\mathrm{d}}$ value of $3.84 \pm 0.29 \mu \mathrm{M}$ was obtained. This value was compared with that obtained for ${ }^{4} \mathrm{~L}_{2} \mathrm{AuCl}$ (Figure 5). The emission spectrum shows a very weak emission at $511 \mathrm{~nm}$, while the quenching effect is still observable. The $\mathrm{K}_{\mathrm{d}}$ value for the ${ }^{4} \mathrm{~L}_{2} \mathrm{AuCl}$ with DHFR adduct is $4.42 \pm 0.56 \mu \mathrm{M}$. The plots for the $\mathrm{K}_{\mathrm{d}}$ analysis are reported in Figure 6.

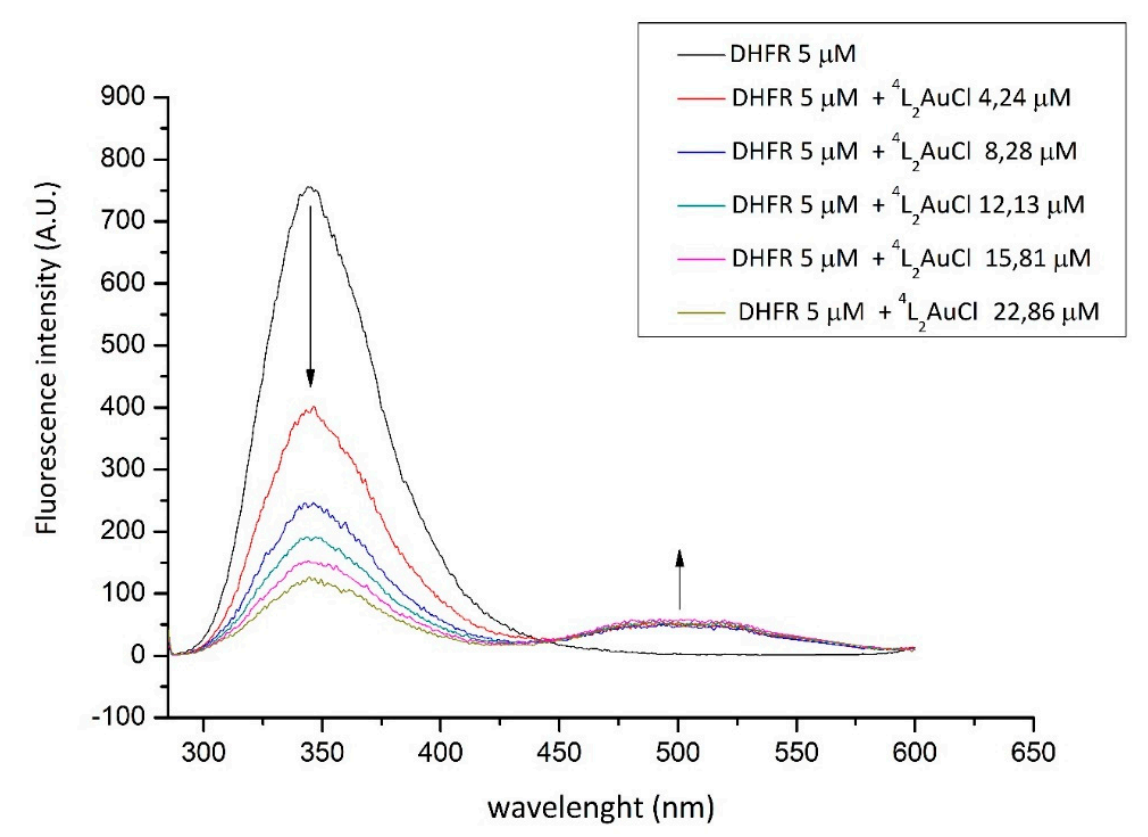

Figure 5. DHFR's tryptophan emission quenching upon stepwise additions of ${ }^{4} \mathrm{~L}_{2} \mathrm{AuCl}\left(\lambda_{\text {exc }}=280 \mathrm{~nm}\right)$. In the inset legend, the color corresponds to the curve and the respective concentrations. 

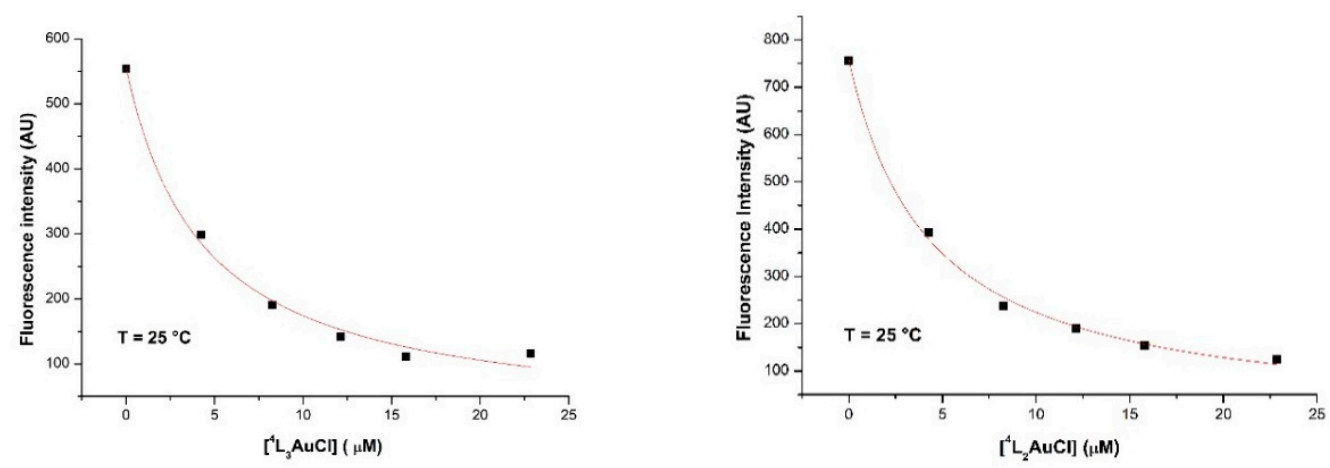

Figure 6. Fluorescence intensity values against added concentration of ${ }^{4} \mathrm{~L}_{3} \mathrm{AuCl}\left(\right.$ left) and ${ }^{4} \mathrm{~L}_{2} \mathrm{AuCl}$ (right) at $25^{\circ} \mathrm{C}$.

To investigate the nature of the binding between the quencher- $\mathrm{Au}$, DHFR, the free 4-benzoic-diphenyl-phosphane acid ligand, i.e., $4-\mathrm{COOHPh}_{2} \mathrm{P}$, and the benzoic acid were assayed in the same conditions. The $\mathrm{K}_{\mathrm{d}}$ values are reported in Table 2 and the spectra are reported in the supplementary material section (Figure S3). These compounds, which are a structural part of the ${ }^{4} \mathrm{~L}_{3} \mathrm{AuCl}$, show looser or negligible static interactions than those observed with gold compounds. These results might be explained in term of accessibility to the tryptophan of the polar benzoic acid on comparison with the lipophilic phosphane ligand, ${ }^{4} \mathrm{~L}[25]$.

With the same aim, the binding of $\left(\mathrm{PPh}_{3}\right)_{2} \mathrm{AuCl}$ (labeled as $\left.\mathrm{L}_{2} \mathrm{AuCl}\right)$ in regard to DHFR was evaluated in terms of the binding interaction (Figure 7).

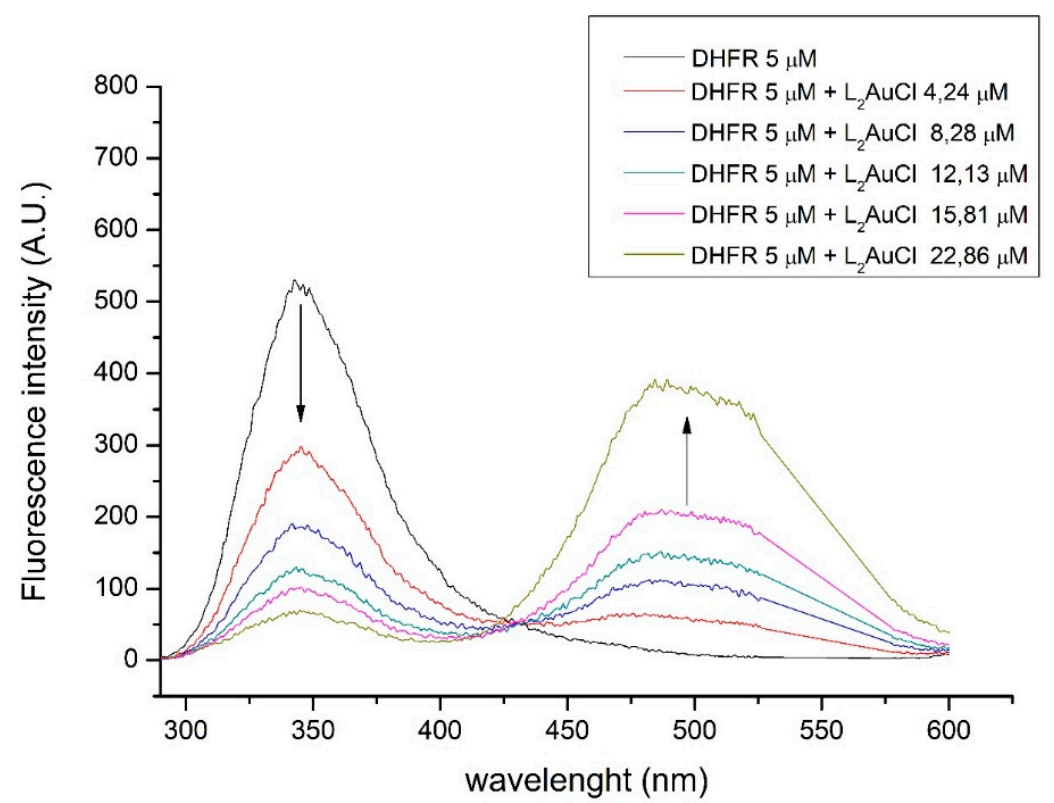

Figure 7. Quenching of DHFR's tryptophan emissions according to the stepwise addition of $\left(\mathrm{PPh}_{3}\right)_{2} \mathrm{AuCl}$ $\left(\lambda_{\text {exc }}=280 \mathrm{~nm}\right)$. In the inset legend, the color corresponds to the curve and the respective concentrations.

The substitution of the chloride with triflate or the esterification of the carboxylic group results in an increase of the $K_{d}$ values, indicating less affinity of the gold complex for the enzyme than what was observed for the ${ }^{4} \mathrm{~L}_{3} \mathrm{AuCl}$ compound (see Table 2).

After these preliminary emissive property characterizations, the fluorimetric studies were led in the presence of the enzyme DHFR and the cofactor NADPH [26]. DHFR possesses five amino-acid tryptophan residues and four tyrosine residues: both aromatic residues show intense emissive properties, and the enzyme's tryptophan, if excited at $280 \mathrm{~nm}$, exhibits an emission at 340-350 nm [18,27]. Additionally, NADPH is fluorescent, with an absorption maximum at about $340 \mathrm{~nm}$ and an emission 
maximum at about $450 \mathrm{~nm}$ [18]. In the presence of NADPH, the enzyme's emission intensity is then quenched by $65 \%$, indicating that tryptophan's environment in the enzyme is significantly altered by the binding of cofactor. Moreover, because NADPH has a maximum of absorption at $340 \mathrm{~nm}$, significant energy transfer from the excited tryptophan of the enzyme to bound NADPH occurs; as a consequence, a new emission at $420-450 \mathrm{~nm}$ is then observed [28]. Figure 8 reports the progressive quenching of the DHFR and NADPH emissions by stepwise adding of solution of ${ }^{4} \mathrm{~L}_{3} \mathrm{AuCl}$. Moreover, a slight shift of the typical emission at $510 \mathrm{~nm}\left(\lambda_{\text {exc }}=280 \mathrm{~nm}\right)$ is observed.

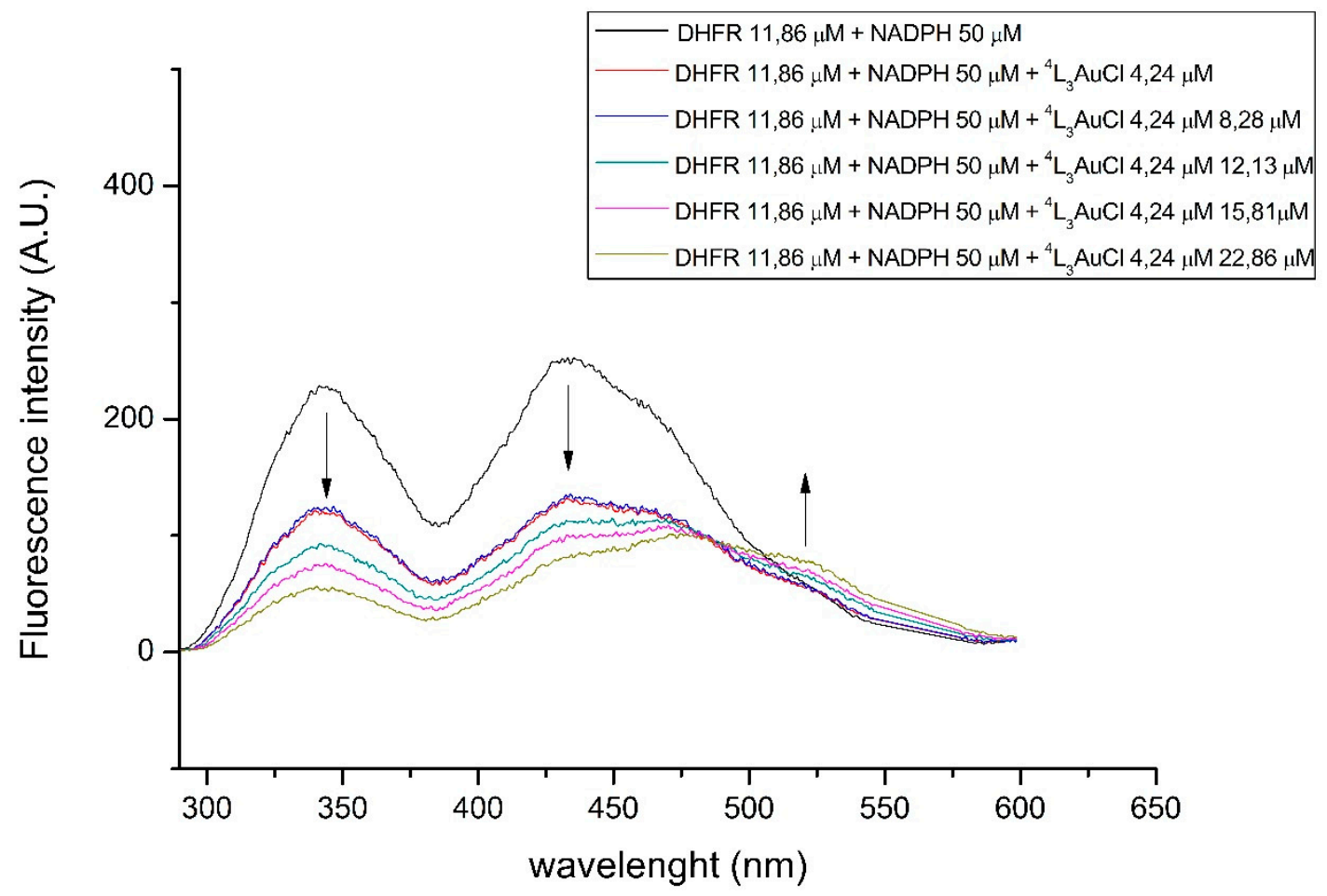

Figure 8. Emission spectra recorded upon the addition of Hepes/methanol solution of ${ }^{4} \mathrm{~L}_{3} \mathrm{AuCl}$ into the DHFR solution saturated with NADPH $\left(\lambda_{\mathrm{exc}}=280 \mathrm{~nm}\right)$. In the inset legend, the color corresponds to the curve and the respective concentration.

To give an insight into the emission spectra shown in Figure 8, the fluorescence spectra were also recorded for the solution of NADPH upon the addition of the gold complexes in absence of the DHFR (data reported in Table 2, rightmost column).

In Figure 9, the emissions recorded upon the stepwise addition of solution of ${ }^{4} \mathrm{~L}_{3} \mathrm{AuCl}$ to NADPH solution at $25{ }^{\circ} \mathrm{C}$ are reported $\left(\lambda_{\mathrm{exc}}=280 \mathrm{~nm}\right)$. The spectra show a modification of the emissions attributed to NADPH, with a likely quenching either of the nicotinamide or of the adenine moieties, while the hyperchromic effect of the emission due to the gold complex is not observed. This modification of the emission maxima might be diagnostic of an interaction of the ${ }^{4} \mathrm{~L}_{3} \mathrm{AuCl}$ to NADPH, which is also strongly interactive with the DHFR. An interaction between NADPH and ${ }^{4} \mathrm{~L}_{3} \mathrm{AuCl}$ is also revealed by the emission spectrum of the mixture of the two molecules in comparison with the individual spectra, reported in Figure 10: the cumulative spectrum of NADPH and ${ }^{4} \mathrm{~L}_{3} \mathrm{AuCl}$ is not the resulting sum of the emission intensities of the two compounds analyzed separately. 


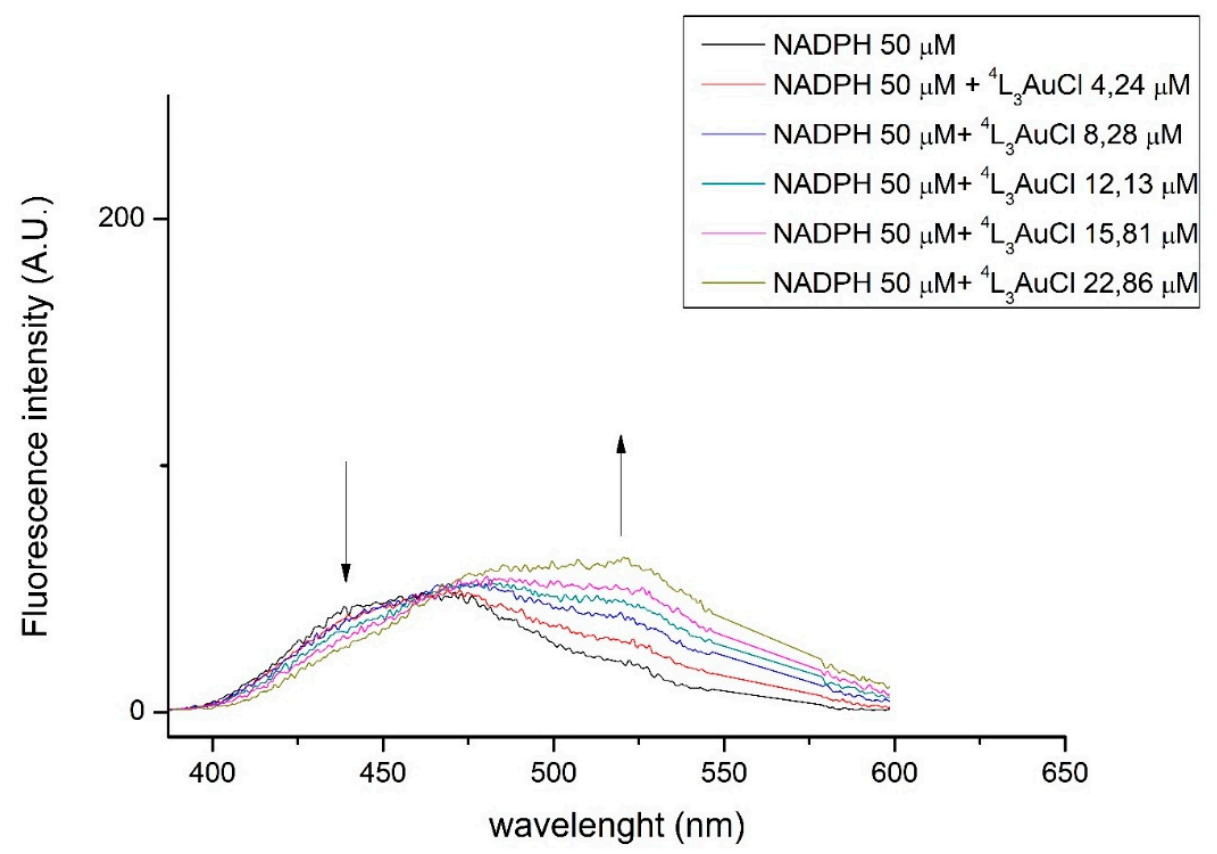

Figure 9. Emission spectra of $50 \mu \mathrm{M}$ solution of NADPH upon adding an increased amount of ${ }^{4} \mathrm{~L}_{3} \mathrm{AuCl}$ $\left(\lambda_{\text {exc }}=280 \mathrm{~nm}\right)$.

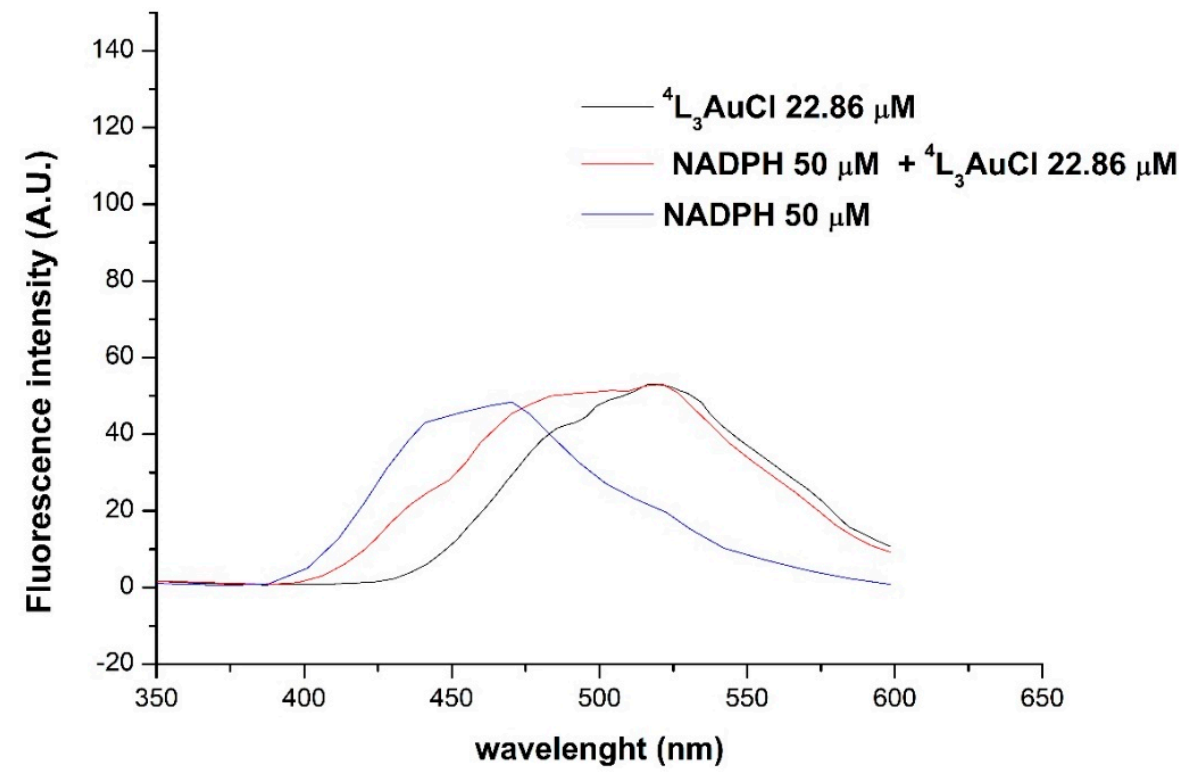

Figure 10. Comparison of the emission spectra recorded for NADPH $50 \mu \mathrm{M}$ (blue line), ${ }^{4} \mathrm{~L}_{3} \mathrm{AuCl} 22.86$ $\mu \mathrm{M}$ (black line), and the mixture of them (red line).

As can be seen from Table 2, most of the $K_{d}$ values have been obtained at different temperatures; 25,10 , and $-4{ }^{\circ} \mathrm{C}$. In general, the trend of the $\mathrm{K}_{\mathrm{d}}$ values results in a lowering upon cooling, even though some discrepancies are observed mainly at $-4{ }^{\circ} \mathrm{C}$, where the solubility of the gold compounds is sometime critical. In Table 3, the fluorimetric data processed according to the vant'Hoff equation and the standard free energy equation $\Delta \mathrm{G}^{\circ}=\Delta \mathrm{G}^{\circ}-\mathrm{T} \Delta \mathrm{S}^{\circ}$ are reported. In all the cases, negative values of $\Delta \mathrm{G}^{\circ}$ remark the spontaneous event of the binding, with a prevalent negative enthalpy contribution, apart from the compound ${ }^{4} \mathrm{~L}_{2} \mathrm{AuCl}$, for which the entropic energy prevails. Notably, this compound shows an anomaly in the trend of the Ki compared to other analogs. 
Table 3. Thermodynamic data for tris and bisphosphane gold complexes.

\begin{tabular}{|c|c|c|c|c|}
\hline Compounds & $\Delta \mathbf{H}^{\circ}(\mathrm{kcal} / \mathrm{mol})$ & $\Delta \mathrm{S}^{\circ}(\mathrm{cal} / \mathrm{mol} \mathrm{K})$ & $\mathrm{T} \Delta \mathrm{S}^{\circ}(\mathrm{kcal} / \mathrm{mol})$ & $\Delta \mathrm{G}^{\circ}(\mathrm{kcal} / \mathrm{mol})$ \\
\hline${ }^{4} \mathrm{~L}_{3} \mathrm{AuCl}$ & $-5.04 \pm 0.08$ & $7.34 \pm 0.005$ & $2.19 \pm 0.1$ & $-7.23 \pm 0.12$ \\
\hline${ }^{4} \mathrm{~L}_{3} \mathrm{AuTfl}$ & $-5.32 \pm 3.2$ & $3.92 \pm 8.8$ & $1.17 \pm 0.9$ & $-4,15 \pm 3.3$ \\
\hline $4 \mathrm{Me}_{2} \mathrm{AuCl}$ & $-4.35 \pm$ n. d. * & $7.69 \pm$ n. d. * & $2.29 \pm$ n. d. $*$ & $-6.64 \pm$ n. d. $*$ \\
\hline${ }^{2} \mathrm{~L}_{3} \mathrm{AuCl}$ & $-3.94 \pm 0.1$ & $9.58 \pm 0.08$ & $2.86 \pm 0.1$ & $-6.8 \pm 0.14$ \\
\hline${ }^{4} \mathrm{~L}_{2} \mathrm{AuCl}$ & $-2.02 \pm 0.2$ & $17.76 \pm 0.1$ & $5.29 \pm 0.2$ & $-7.31 \pm 0.28$ \\
\hline $\mathrm{L}_{2} \mathrm{AuCl}$ & $-4.87 \pm$ n. d. ${ }^{*}$ & $8.42 \pm$ n. d. ${ }^{*}$ & $2.5 \pm$ n. d. $*$ & $-7.37 \pm$ n. d. $*$ \\
\hline
\end{tabular}

* n. $\bar{d}$. $=$ not determined. Data are available only at two temperatures $\left(10\right.$ and $\left.25^{\circ} \mathrm{C}\right)$ because of loss of solubility.

\subsection{Spectrometric Studies by ESI-MS}

Some additional studies have been led by using the ESI Mass Spectrometry [29]. In this regard, the DHFR enzyme has already been the object of several studies mainly addressed to the structural characterization [30] or to the binding of the metal to the enzyme's fragment [31]. At first, buffered solutions of ${ }^{4} \mathrm{~L}_{2} \mathrm{AuCl}$ or ${ }^{4} \mathrm{~L}_{3} \mathrm{AuCl}$ and $\mathrm{H} 2 \mathrm{~F}$ in the presence or in the absence of NADPH were analyzed by ESI-MS to rule out the possibility of having the reduction of DHF to THF activated by gold compounds, the catalytic actions of which, in regards to many reactions, are already known [32,33]. From the analysis of the peaks and the comparison with standards of $\mathrm{H} 2 \mathrm{~F}$ and $\mathrm{H} 4 \mathrm{~F}$, we could exclude this hypothesis. However, additional spectra were recorded on buffered solutions containing NADPH and ${ }^{4} \mathrm{~L}_{2} \mathrm{AuCl}$ or ${ }^{4} \mathrm{~L}_{3} \mathrm{AuCl}$ to analyze the interaction between the cofactor and the gold complex. In the former case, in the range $250-800 \mathrm{~m} / \mathrm{z}$, peaks due to $\left[{ }^{4} \mathrm{~L}^{-}(304.8 \mathrm{~m} / \mathrm{z}),\left[{ }^{4} \mathrm{~L}_{2} \mathrm{Au}\right]^{2-}(403 \mathrm{~m} / \mathrm{z})\right.$ and $\left[{ }^{4} \mathrm{LAuCH}_{3} \mathrm{COO}\right]^{-}(560.8 \mathrm{~m} / \mathrm{z})$ were detected; other peaks were attributed to NADPH, such as [NADPH] ${ }^{2-}$ at $371 \mathrm{~m} / \mathrm{z}$. The most characteristic peaks were found in the range $600-1000 \mathrm{~m} / \mathrm{z}$. In particular, in addition to the peak of [NADPH] ${ }^{-}$at $743.9 \mathrm{~m} / \mathrm{z}$, a quite intense peak at $765.8 \mathrm{~m} / \mathrm{z}$ might be attributed to the doubly charged ion $\left[2 \mathrm{NADPH}+{ }^{4} \mathrm{~L}_{2} \mathrm{Au}-\mathrm{H}_{2} \mathrm{O}\right]^{2-}$. For this peak, a reaction between the carboxylic group and the amine function of the adenine moiety with the loss of water might be speculated. The spectrum is reported in Figure 11.

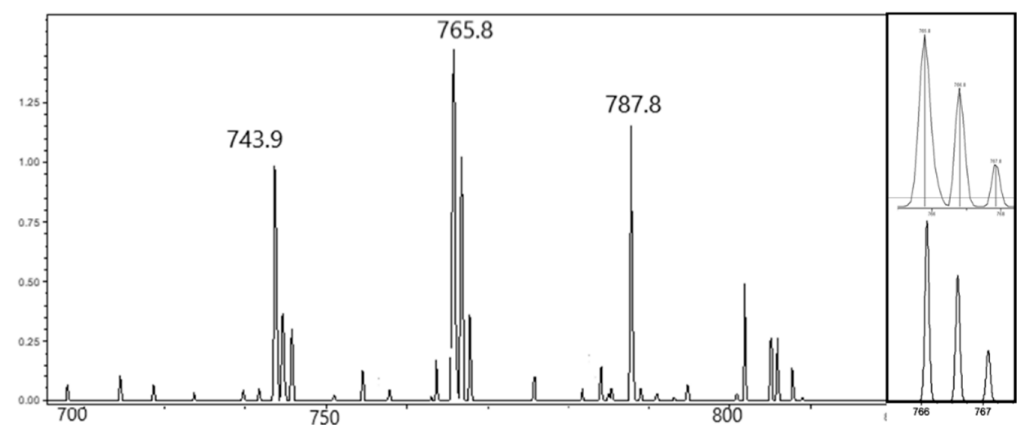

Figure 11. ESI-MS spectrum in the range $700-830 \mathrm{~m} / \mathrm{z}$ for negative ions recorded for NADPH in ammonium acetate and ${ }^{4} \mathrm{~L}_{2} \mathrm{AuCl}$ upon incubation of $5 \mathrm{~min}$. Magnification of the peak at $765.8 \mathrm{~m} / \mathrm{z}$ for [2NADPH + $\left.{ }^{4} \mathrm{~L}_{2} \mathrm{Au}-\mathrm{H}_{2} \mathrm{O}\right]^{2-}$ (top, right image) and its simulation with IsoPro3.0 (bottom, right image).

\section{Materials and Methods}

\subsection{Syntheses}

The preparation of the gold compounds was performed according to methods already published $[14,15]$ and was based on the substitution of the labile ligand from the gold precursor [ $\left.\mathrm{AuCl}\left(\mathrm{Me}_{2} \mathrm{~S}\right)\right]$, by mean of a more coordinative ligand, such as the $\mathrm{PPh}_{3}$ or its modified analogs, ${ }^{4} \mathrm{~L}$ and ${ }^{2} \mathrm{~L}$. Mole ratio with an excess of the phosphane ligand was pursued with the aim to enhance the reaction yield for tris-phosphane compounds. The solids obtained by crystallization were characterized by elemental analysis, ${ }^{1} \mathrm{H}$ and ${ }^{31} \mathrm{P}$ NMR, IR, and ESI Mass spectrometry. The stability of the stock solutions upon dilution was checked by 
recording UV-visible spectra (see Supplementary Material, Figures S1 and S2). The reactants for the ester reaction and ${ }^{4} \mathrm{~L}$ or ${ }^{2} \mathrm{~L}$ ligands were bought from Aldrich and used without any purification. Methanol or methylene chloride solvents were degassed and dried over molecular sieves.

\subsubsection{Synthesis of 4-(diphenylphosphanyl)benzoic acid methyl ester, ${ }^{4 \mathrm{Me}} \mathrm{L}$}

The title compound was prepared according to the procedure described by Yoakim. ${ }^{29}$ To a $15 \mathrm{~mL}$ solution of 4-(diphenylphosphino)benzoic acid (398 mg; $1.30 \mathrm{mmol}$ ) in $\mathrm{CH}_{2} \mathrm{Cl}_{2}$ anhydrous, methanol $(0.05 \mathrm{~mL} ; 1.4 \mathrm{mmol})$ and $\mathrm{N}, \mathrm{N}$-dimethylaminopyridine $(37.0 \mathrm{mg} ; 0.30 \mathrm{mmol})$ were added. A solution of $\mathrm{N}, \mathrm{N}$-dicyclohexylcarbodiimide ( $300 \mathrm{mg} ; 1.41 \mathrm{mmol}$ ) in $\mathrm{CH}_{2} \mathrm{Cl}_{2}$ was added over $15 \mathrm{~min}$ at $0^{\circ} \mathrm{C}$. The resulting pale yellow suspension was stirred for $16 \mathrm{~h}$ at room temperature. The suspension was filtered and dried at reduced pressure. The solid was dissolved with EtOAc $(30 \mathrm{~mL})$, washed successively with aqueous $10 \% \mathrm{HCl}(15 \mathrm{~mL})$, saturated $\mathrm{NaHCO}_{3}(15 \mathrm{~mL})$, and brine $(15 \mathrm{~mL})$. The organic fraction was dried over $\mathrm{MgSO}_{4}$, filtered, and evaporated to dryness. The solid was dissolved in EtOAc and purified with flash chromatography ( $5 \%$ EtOAc/hexane). The product was crystallized as a white solid, with cyclohexane. Yield: $60 \%$.

${ }^{1} \mathrm{H} \mathrm{NMR}\left(\mathrm{CDCl}_{3}, \delta\right): 8.05(\mathrm{~d}, 2 \mathrm{H}) ; 7.35-7.40(\mathrm{~m}, 12 \mathrm{H}) ; 3.95(\mathrm{~s}, 3 \mathrm{H})$.

${ }^{31} \mathrm{P}$ NMR $\left(\mathrm{CDCl}_{3,}, \delta\right):-5.02(\mathrm{~s})$.

MIR ( $\left.\mathrm{cm}^{-1}\right)$ : $3067(\mathrm{w}), 2999(\mathrm{w}), 2952(\mathrm{w}), 2924(\mathrm{w}), 2852(\mathrm{w}), 2102(\mathrm{w}), 1943(\mathrm{w}), 1822(\mathrm{w}), 1719(\mathrm{vs})$, 1597 (m, sh), 1584 (sh), 1561 (w), 1476 (m), 1433 (s), 1393 (m), 1278 (vs), 1181 (m), 1115 (m), 1088 (s), 1017 (s), 999 (sh), 965 (m), 857 (m), 750 (m), 743 (vs).

\subsubsection{Synthesis of [tris(4-benzoate-diphenylphosphanyl)-gold(I)chloride], ${ }^{4} \mathrm{~L}_{3} \mathrm{AuCl}$}

The solution of 4-(diphenylphosphine)benzoic acid (208.3 mg; $0.4 \mathrm{mmol}$ ) in $\mathrm{CHCl}_{3}$; was added dropwise to the solution of (dimethylsulfide)gold(I)chloride ( $30 \mathrm{mg} ; 0.1 \mathrm{mmol})$ in $\mathrm{CHCl}_{3} ;(3 \mathrm{~mL})$ at 0 ${ }^{\circ} \mathrm{C}$. The mixture was stirred at $\mathrm{r}$. t. overnight. A pale yellow precipitate was obtained. Upon filtration, the solid was recovered and dissolved with $\mathrm{MeOH}$ and filtered again over a paper filter. The product was crystallized, as pale yellow solid, from a mixture of $\mathrm{CHCl}_{3}$; and cyclohexane.

Yield: $86 \%$. M. p. $139-140{ }^{\circ} \mathrm{C}$.

Analyzing the product:

${ }^{1} \mathrm{H}-\mathrm{NMR}\left(\mathrm{CD}_{3} \mathrm{OD}, \delta\right): 7.81(\mathrm{~d}, 6 \mathrm{H}) ; 7.50(\mathrm{t}, 6 \mathrm{H}), 7.26(\mathrm{~m}, 30 \mathrm{H})$.

${ }^{31}$ P-NMR ( $\left.\mathrm{CD}_{3} \mathrm{OD}, 8\right): 42.09$ (s).

MIR (cm $\left.{ }^{-1}\right)$ : $3484(\mathrm{~s}, \mathrm{br}), 3054$ (m, br), 1702.9 (vs), 1597.9 (s), 1560.2 (s), 1481 (m), 1434 (s), 1393 (s), $1310.9(\mathrm{~m}), 1275(\mathrm{~m}, \mathrm{sh}), 1225(\mathrm{vs}), 1183(\mathrm{~s}), 1122.6(\mathrm{~m}), 1091.8(\mathrm{~s}), 1025.9(\mathrm{~m}), 1016.8(\mathrm{~s}), 998.9(\mathrm{~m}), 855$ $(\mathrm{m}-\mathrm{w}), 791.9(\mathrm{~m}), 764(\mathrm{~s}, \mathrm{sh}), 742.8(\mathrm{~s}), 689.9(\mathrm{vs})$.

FIR $\left(\mathrm{cm}^{-1}\right)$ : $534(\mathrm{w}), 513.5(\mathrm{~m}), 367.8(\mathrm{w}), 295.68(\mathrm{w}), 176.95(\mathrm{~m}), 139(\mathrm{~m}), 125.7(\mathrm{~m}), 106(\mathrm{w}), 58.43(\mathrm{~m})$, $39.8(\mathrm{~m})$.

ESI (-) $\left(\mathrm{CH}_{3} \mathrm{OH}, \mathrm{m} / \mathrm{z}\right): 305.2$ (100), 536.9 (40). ESI (+) $\left(\mathrm{CH}_{3} \mathrm{OH}, \mathrm{m} / \mathrm{z}\right): 808.9$ (100) [(4-COOH-Ph$\left.\left.{ }_{2} \mathrm{P}\right)_{2} \mathrm{Au}\right]^{+}$. Elemental analysis for $\mathrm{C}_{57} \mathrm{H}_{51} \mathrm{AuClO}_{9} \mathrm{P}_{3}$, calculated\%: C 56.80, H 4.26. Found C 56.86, H 4.13.

\subsubsection{Synthesis of [tris(4-benzoate-diphenylphosphanyl)-gold(I)triflate], ${ }^{4} \mathrm{~L}_{3} \mathrm{AuTfl}$}

A solution of silver trifuoromethanesulfonate $(87 \mathrm{mg}, 0.34 \mathrm{mmol})$ was dissolved in $1 \mathrm{~mL}$ of dry THF and then added to a solution of (dimethylsulfide)gold(I)chloride (100 mg; $0.34 \mathrm{mmol}$ ) in $12 \mathrm{~mL}$ of THF. A precipitate of $\mathrm{AgCl}$ was readily formed. The mixture was rapidly filtered over celite, under nitrogen flux. The clean filtrate was transferred in another flask containing the 4-(diphenylphosphino)benzoic acid in THF $(2 \mathrm{~mL})$. The mixture was stirred at $\mathrm{r}$. t. for $3 \mathrm{~h}$. After evaporation to dryness, a white pale yellow compound was obtained. Then, it was washed with hexane and diethyl ether and crystallized from chloroform and hexane.

Yield: $85 \%$. M. p. $153-154{ }^{\circ} \mathrm{C}$.

${ }^{1} \mathrm{H}-\mathrm{NMR}$ (Acetone- $\left.\mathrm{d}^{6}, \delta\right) 7.81(\mathrm{~d}, \mathrm{~J}=7.6 \mathrm{~Hz}, 6 \mathrm{H}) ; 7.48(\mathrm{~m}, 6 \mathrm{H}) ; 7.28(\mathrm{~m}, 30 \mathrm{H})$.

${ }^{31}$ P-NMR (Acetone-d ${ }^{6}, \delta$, r. t.) 32.61 (s), 22.59 (s). 
MIR ( $\left.\mathrm{cm}^{-1}\right)$ : 3053 (m, br), 2546 (m, br), 1693 (vs), 1597.7 (m), 1560 (m), 1482 (m), 1435 (vs), 1414 (m, sh), 1395 (m), 1315 (m), 1290 (s), 1221 (vs), 1179 (m), 1157 (s,sh), 1095 (vs), 1027 (s, sh), 1017 (m), 999 (m), $926(\mathrm{~m}, \mathrm{br}), 854(\mathrm{~m}), 793.3(\mathrm{w}), 743(\mathrm{~m}), 690(\mathrm{vs})$.

ESI (-) $\left(\mathrm{CH}_{3} \mathrm{OH}, \mathrm{m} / \mathrm{z}\right): 305.2(100)$. ESI $(+)\left(\mathrm{CH}_{3} \mathrm{OH}, \mathrm{m} / \mathrm{z}\right): 808.9(100)\left[\left(4-\mathrm{COOH}-\mathrm{Ph}_{2} \mathrm{P}\right)_{2} \mathrm{Au}\right]^{+}$. Elemental analysis for $\mathrm{C}_{58} \mathrm{H}_{45} \mathrm{AuF}_{3} \mathrm{O}_{9} \mathrm{P}_{3} \mathrm{~S}+3 \mathrm{H}_{2} \mathrm{O}$, calculated\%: $\mathrm{C} 56.20 ; \mathrm{H} 3.69, \mathrm{~S} 2.06$. Found\%: C 56.07; H 3.59, S 2.53.

\subsubsection{Synthesis of [tris(2-benzoate-diphenylphosphanyl)-gold(I)chloride], ${ }^{2} \mathrm{~L}_{3} \mathrm{AuCl}$}

The solution of 2-(diphenylphosphine) benzoic acid (208.3 mg; $0.4 \mathrm{mmol}$ ) in $\mathrm{CHCl}_{3}$; was added dropwise to the solution of (dimethylsulfide)gold(I)chloride $(30 \mathrm{mg} ; 0.1 \mathrm{mmol})$ in $\mathrm{CHCl}_{3} ;(3 \mathrm{~mL})$ at 0 ${ }^{\circ} \mathrm{C}$. The mixture was stirred at r.t overnight. A pale yellow precipitate was obtained. The compound was recovered upon filtration, completely dissolved with $\mathrm{MeOH}$, and evaporated. The product was crystallized, as pale yellow solid, from a mixture of $\mathrm{CHCl}_{3}$; and cyclohexane.

Yield: $88 \%$.

${ }^{1} \mathrm{H}-\mathrm{NMR}\left(\mathrm{CD}_{3} \mathrm{OD}, \delta\right): 8.51(\mathrm{~d}, 3 \mathrm{H}) ; 7.73(\mathrm{t}, 6 \mathrm{H}), 7.45(\mathrm{dt}, 6 \mathrm{H}), 7.06(\mathrm{~m}, 30 \mathrm{H})$.

${ }^{31} \mathrm{P}-\mathrm{NMR}\left(\mathrm{CD}_{3} \mathrm{OD}, \delta\right): 47.09$ (s).

IR ( $\left.\mathrm{cm}^{-1}\right)$ : $3054(\mathrm{w}), 1699(\mathrm{vs}), 1596(\mathrm{w}), 1584(\mathrm{w}), 1565(\mathrm{w}), 1471(\mathrm{w}), 1433(\mathrm{vs}), 1388(\mathrm{vs}), 1265(\mathrm{w})$, 1222 (vs), 1179 (w), 1114 (s), 1091 (s), 1027, 999, 799 (s), 742 (vs), 688 (vs), 642 (vs), 522 (s), 506 (s), 446 $(\mathrm{m}), 432(\mathrm{~m})$.

ESI (-) $\left(\mathrm{CH}_{3} \mathrm{OH}, \mathrm{m} / \mathrm{z}\right): 305.2(100), 536.9$ (40). ESI (+) $\left(\mathrm{CH}_{3} \mathrm{OH}, \mathrm{m} / \mathrm{z}\right): 808.9(100)\left[\left(2-\mathrm{COOH}-\mathrm{Ph}_{2} \mathrm{P}\right)_{2} \mathrm{Au}\right]^{+}$. Elemental analysis for $\mathrm{C}_{57} \mathrm{H}_{45} \mathrm{AuClO}_{6} \mathrm{P}_{3}$, calculated\%: C 61.35, H 4.06. Found C 60.98, H 4.23.

\subsubsection{Synthesis of [tris(4-methylbenzoate)-diphenylphosphanyl)-gold(I)chloride], ${ }^{4 \mathrm{Me}_{3} \mathrm{AuCl}}$}

The solution of methyl 4-(diphenylphosphino)benzoate $(64 \mathrm{mg} ; 0.2 \mathrm{mmol})$ in anhydrous $\mathrm{CHCl}_{3}$; $(2 \mathrm{~mL})$ was added dropwise to the solution of (dimethylsulfide)gold(I)chloride ( $15 \mathrm{mg} ; 0.05 \mathrm{mmol})$ in $\mathrm{CHCl}_{3} ;(3 \mathrm{~mL})$ at $0{ }^{\circ} \mathrm{C}$. The mixture was stirred at r.t. overnight, then filtered and dried at reduced pressure. The pale yellow solid was washed in hexane to remove the excess of dimethylsulfide and crystallized by $\mathrm{CHCl}_{3}$ solutions.

Yield: $67 \%$.

${ }^{1} \mathrm{H}-\mathrm{NMR}\left(\mathrm{CDCl}_{3}, \delta\right): 7.97(\mathrm{~d}, 6 \mathrm{H}) ; 7.69(\mathrm{~d}, 6 \mathrm{H}), 7.29-7.44(\mathrm{~m}, 30 \mathrm{H}), 3.95(\mathrm{~s}, 9 \mathrm{H})$.

${ }^{31} \mathrm{P}-\mathrm{NMR}\left(\mathrm{CDCl}_{3}, \delta\right): 30.57$ (s).

MIR (cm $\left.{ }^{-1}\right)$ : $3052(\mathrm{w}), 3008(\mathrm{w}), 2953(\mathrm{w}), 2924(\mathrm{w}), 2852(\mathrm{w}), 2103(\mathrm{w}, \mathrm{br}), 1980(\mathrm{w}, \mathrm{br}), 1812(\mathrm{w}), 1718$ (vs), $1597(\mathrm{~m}), 1559$ (sh), 1560 (w), $1480(\mathrm{~m}), 1434$ (s), 1394 (m), 1273 (vs), $1186(\mathrm{~m}), 1110$ (s), 1089 (s), 1018 (s), 999 (sh), 963 (w), 952 (m), 804 (m), 743 (vs).

ESI (+) $\left(\mathrm{CH}_{3} \mathrm{OH}, \mathrm{m} / \mathrm{z}\right): 517 \mathrm{~m} / \mathrm{z}(30)\left[\left(4-\mathrm{COOCH}_{3}-\mathrm{Ph}_{2} \mathrm{P}\right) \mathrm{Au}\right]^{+} ; 838(100)\left[\left(4-\mathrm{COOCH}_{3}-\mathrm{Ph}_{2} \mathrm{P}\right)_{2} \mathrm{Au}\right]^{+}$. Elemental analysis for $\mathrm{C}_{60} \mathrm{H}_{51} \mathrm{AuClO}_{6} \mathrm{P}_{3}$, calculated\%: C 60.39, $\mathrm{H}$ 4.31. Found C 60.77, H 4.76.

\subsection{Enzyme Inhibition Studies}

\subsubsection{Preparation of the NADPH Stock}

$3.2 \mathrm{mg}$ of NADPH was dissolved in $1 \mathrm{~mL}$ of Hepes (4-(2-hydroxyethyl)-1-piperazine1-ethanesulfonate) $50 \mathrm{mM}$ buffer solution at $\mathrm{pH}=7.3$. The concentration of NADPH solution was determined by UV-Vis spectroscopy, using the buffer solution as a blank, and diluting the stock solution 1: 50 (20 mL of NADPH stock in $1 \mathrm{~mL}$ solution). The absorbance was recorded at $340 \mathrm{~nm}$ (for NADPH $\varepsilon_{340}=6220 \mathrm{M}^{-1} \cdot \mathrm{cm}^{-1}$ ).

\subsubsection{Preparation of the H2F Stock}

$1 \mathrm{mg}$ of $\mathrm{H} 2 \mathrm{~F}$ stock was dissolved in $600 \mu \mathrm{L}$ of HEPES buffer $50 \mathrm{mM}$ and $38 \mu \mathrm{L}$ of $\beta$-mercapto-ethanol. The $\mathrm{KOH} 0.01 \mathrm{M}$ was used as the blank and to dilute the stock solution to 1:200. The absorbance was read at $283 \mathrm{~nm}$ (for $\mathrm{H} 2 \mathrm{~F} \varepsilon_{283}=28,000 \mathrm{~cm}^{-1}$ ). 


\subsubsection{Preparation of the DHFR Stock}

The overexpressed and purified DHFR from Escherichia coli was stored at $4{ }^{\circ} \mathrm{C}$ and precipitated in a $90 \%\left(\mathrm{NH}_{4}\right)_{2} \mathrm{SO}_{4}$ solution. The dialysis of DHFR was performed in two steps with a $10 \mathrm{mM}$ $\mathrm{K}_{2} \mathrm{HPO}_{4}-\mathrm{KH}_{2} \mathrm{PO}_{4}$ buffer, $\mathrm{pH}=7.3$, the first in $3 \mathrm{~h}$ and the second overnight. The concentration of DHFR was determined by recording the absorbance of the stock solution at $280 \mathrm{~nm}$ (E. coli DHFR $\varepsilon_{280}$ $=31,100 \mathrm{M}^{-1} \mathrm{~cm}^{-1}$ ) using the potassium phosphate buffer as the blank.

\subsubsection{Preparation of the Gold(I) Compounds Stocks}

$5 \mathrm{mg}$ of gold(I) compounds were dissolved in $5 \mathrm{~mL}$ of methanol, affording approximately $1 \mu \mathrm{M}$ solutions. The concentration of the gold(I) compounds were calculated knowing the molar masses.

\subsection{Inhibition Studies on DHFR}

The activity of the DHFR was followed by recording the absorbance with a Shimadzu UV-2450 (UV-Vis spectrophotometer). The enzyme assays were made in a quartz cuvette by using similar experimental conditions: DHFR 3-5 nM, NADPH 60-80 $\mu \mathrm{M}$, and H2F 1.5, 4, and $10 \mu \mathrm{M}$. The procedure consisted in the preparation of the following mixtures: $800-971 \mu \mathrm{L}$ of $50 \mathrm{mM}$ Hepes buffer at $\mathrm{pH}=7.3,20 \mu \mathrm{L}$ of NADPH, $10 \mu \mathrm{l}$ of DHFR, and increasing quantities of gold(I) compounds stock solutions in order to achieve higher accuracy in the measurement of the inhibitory effect. After storing the mixture for $5 \mathrm{~min}$ at $30^{\circ} \mathrm{C}, 4-33 \mu \mathrm{L}$ of $\mathrm{H} 2 \mathrm{~F}$ was added. The decreasing absorbance at $340 \mathrm{~nm}$, due to the oxidation of NADPH to NADP ${ }^{+}$, was detected after adding the $\mathrm{H} 2 \mathrm{~F}$, and expressed in $\mathrm{U} \mathrm{mL}^{-1}$ using the equation: $\mathrm{U} \cdot \mathrm{mL}^{-1}=\Delta \mathrm{abs} / \Delta \mathrm{t} / 11.8 \times$ dilution factor, where 11.8 is the mMolar extinction coefficient when NADPH and $\mathrm{H} 2 \mathrm{~F}$ are simultaneously present in solution. The Ki values were calculated with the Dixon plot from the second plot obtained computing the slope values against the reciprocal of the $\mathrm{H} 2 \mathrm{~F}$ concentrations.

\subsection{Fluorimetric Analysis}

The fluorimetric analysis was performed using a $1 \mathrm{~mL}$ quartz cuvette and a Perkin-Elmer Fluorescence Spectrometer LS 55. For all the analysis we used 5-12 $\mu \mathrm{M}$ solutions of DHFR and increasing concentrations of gold(I) compounds in the 4-60 $\mu \mathrm{M}$ range. For some experiments, saturating concentrations of NADPH $(50 \mu \mathrm{M})$ were added to the initial solutions of DHFR to observe the affinity variation of the complexes with respect to the DHFR.

To observe the intrinsic emission of the gold(I) complexes, and eventually their hyperchromic effect, emission spectra were recorded in the same range of concentration used for the quenching studies $(4-60 \mu \mathrm{M})$.

All the emission spectra have been interpolated graphically (Origin Lab ${ }^{\circledR} 2019$ ) [34] in order to correct for the second order Rayleigh scattering band, centered at $560 \mathrm{~nm}$.

All the spectra were recorded in the range between 250 and $600 \mathrm{~nm}$ using an excitation wavelength characteristic of the Tryptophan, equal to $280 \mathrm{~nm}$. For most of the experiments the temperature was kept constant at $25^{\circ} \mathrm{C}$; furthermore, to analyze the thermodynamic aspects of the reactions (via the van't Hoff equation), quenching spectra of DHFR in presence of the gold(I) complexes were recorded at -4 and $10^{\circ} \mathrm{C}$ as well.

The fluorimetric data were analyzed using the binding isotherm (Equation (2)), where [Q] is the concentration of the added quenching ligand, $\mathrm{F}$ is the measured fluorescence, $\mathrm{F}_{0}$ is the starting fluorescence, $F_{c}$ is the fluorescence of the fully complexed protein, $K_{d}$ is the dissociation constant, and $n$ is the Hill coefficient. Indeed, $n$ is a phenomenological parameter, an interaction coefficient, such as when $n=1$ the equation describes a complex formation with one site of interaction, when $n=2$ binding occurs with a dimer, when $1<n<2$ a cooperative interaction occurs [35].

$$
\frac{F 0-F}{F-F c}=\frac{[Q]^{n}}{(K d+[Q])^{n}}
$$




\subsection{ESI-MS Spectrometry}

The instrument used was a HPLC 1100 Agilent Technologies connected to a mass spectrometer Agilent Technologies (LC/MSD Trap SL) equipped with an electrospray ion source (ESI). The analyses have been performed in FIA (flow injection analysis) mode. The mobile phase was $\mathrm{H}_{2} \mathrm{O}: \mathrm{MeOH}$ 90:10 at $300 \mu \mathrm{L} / \mathrm{min}$, with the addition of $0.1 \%$ formic acid. The ionization source parameters were the following: nebulizer pressure $50 \mathrm{psi}$, gas flow $10 \mathrm{~L} / \mathrm{min}$, drying gas temperature $350{ }^{\circ} \mathrm{C}$, capillary voltage 3500 Volts, injection volume $2 \mu \mathrm{L}$.

The solutions of $80 \mu \mathrm{M}$ NADPH and $100 \mu \mathrm{M}{ }^{4} \mathrm{~L}_{2} \mathrm{AuCl}$ have been prepared by dissolving NADPH in ammonium acetate $10 \mathrm{mM} \mathrm{pH} 7.3$ and by adding $100 \mu \mathrm{L}$ of a $1 \mathrm{mM}$ stock solution of the gold compound dissolved in methanol, to a final volume of $1 \mathrm{~mL}$.

\section{Conclusions}

In this work, a class of polyphosphane gold(I) complexes have been assayed as DHFR from E. coli inhibitors and a study about the mechanism of their interaction has been led. For this set of phosphane gold compounds, the strongest inhibition was detected for $\left(\mathrm{PPh}_{3}\right)_{2} \mathrm{AuCl}$ with a value of $\mathrm{Ki}=0.53 \mu \mathrm{M}$, and the same compound shows a remarkable affinity for DHFR with a thermodynamic constant for the dissociation of the adduct [DHFR:( $\left.\mathrm{PPh}_{3}\right)_{2} \mathrm{AuCl}$ ] equal to about $2 \mu \mathrm{M}$. The presence of the $\mathrm{COOH}$ group in the phosphane ligand affords to compounds ${ }^{4} \mathrm{~L}_{2} \mathrm{AuCl}$ or ${ }^{2} \mathrm{~L}_{2} \mathrm{AuCl}$, and it does not introduce a better ability to inhibit the reduction of $\mathrm{H} 2 \mathrm{~F}$ to $\mathrm{H} 4 \mathrm{~F}$ by the DHFR ( $\mathrm{Ki}=27$ and $2 \mu \mathrm{M}$, respectively) and not even to bind the enzyme. Moreover, the conversion of the $\mathrm{COOH}$ into the methyl esther function in the ligand does not introduce big changes in the inhibition $\left(\mathrm{K}_{\mathrm{i}} \approx 13 \mu \mathrm{M}\right)$, nor in the affinity to the $\operatorname{DHFR}\left(\mathrm{K}_{\mathrm{d}} \approx 12.7 \mu \mathrm{M}\right)$. Nevertheless, the presence of gold atom plays a central role in both inhibitory and enzyme-binding activities. The affinity of gold compounds for DHFR in general is enhanced by the presence of NADPH, which yields the interaction to be more specific and behaves as a positive allosteric modulator with respect to all the tested gold compounds. The NADPH cooperative effect on gold compounds binding by DHFR is consistent with its role in the enzyme catalytic mechanism and with the behavior observed for other DHFR inhibitors [36].

Indications about an additional action of NADPH by binding the ${ }^{4} \mathrm{~L}_{2} \mathrm{AuCl}$ has been also evidenced by mass spectrometry, even though the investigation was not exhaustive, the formation of an adduct between NADPH and the gold compound has been observed. In conclusion, the compounds analyzed in this paper show a reversible inhibitory effect that foresees a reversible bond, modulated by the presence of the cofactor, affected by the nature of the phosphane ligands and, unquestionably, by the presence of the gold atom. The reversible bonding is also evidenced by the hyperchromic effect on the intrinsic emission of the phosphane gold compound and by the shift of the emission maxima, due to both the stabilization of the excited state and the binding to the enzyme, respectively. The effect of the temperature on the $\mathrm{K}_{\mathrm{d}}$ values (Table 3 ) characterizes the binding, attributing a modest exothermic contribute in spite of the entropic one. These results may be discussed by considering previous studies on the interaction of gold phosphane compounds and target enzymes, such as Thioredoxine reductase. For this latter, nanomolar IC50 values have been found [13], but for this enzyme, the formation of covalent bonds with cysteine or selenocysteine residues has been largely hypothesized [17,31]. In this work, from the kinetic inhibition and thermodynamic data, we hypothesize a reversible bond, with the enzyme DHFR having both an electrostatic and hydrophobic nature with an interplay mechanism involving the cofactor NADPH, depending on the type of the gold compound. Based on these results, we can infer that enzymes in which the catalytic site does not contain either cysteines or selenocysteines might interact with gold complexes through non-covalent interactions, endowing Ki values in the micromolar order of magnitude.

Supplementary Materials: Supplementary materials can be found at http://www.mdpi.com/1422-0067/20/7/1802/s1.

Author Contributions: R.G. and S.P. equally contributed to this work. S.V. provided partial financial coverage. O.C.S. and A.T.R. prepared the gold compounds and put the basis for this study. M.R. took care about the ESI mass spectra acquisitions in the proper operative conditions. L.L. performed and refined the spectroscopic studies and took part to the elaboration of the data. 
Funding: This research received no external funding.

Acknowledgments: R.G. and S.P. are grateful to CIRCMSB (Consorzio Interuniversitario Ricerca sulla Chimica dei Metalli e le Sostanze Biologiche) and to FAR of the University of Camerino (Fondi di Ateneo per la Ricerca).

Conflicts of Interest: The authors declare no conflict of interest.

\section{References}

1. Cannon, W.R.; Garrison, B.J.; Benkovic, S.J. Electrostatic Characterization of Enzyme Complexes: Evaluation of the Mechanism of Catalysis of Dihydrofolate Reductase. J. Am. Chem. Soc. 1997, 119, 2386-2395. [CrossRef]

2. Schnell, J.R.; Dyson, H.J.; Wright, P.E. Structure, Dynamics, and Catalytic Function of Dihydrofolate Reductase. Annu. Rev. Biophys. Biomol. Struct. 2004, 33, 119-140. [CrossRef] [PubMed]

3. Schweitzer, B.I.; Dicker, A.P.; Bertino, J.R. Dihydrofolate Reductase as a Therapeutic Target. FASEB J. 1990, 4 , 2441-2452. [CrossRef]

4. Hawser, S.; Lociuro, S.; Islam, K. Dihydrofolate Reductase Inhibitors as Antibacterial Agents. Biochem. Pharmacol. 2006, 71, 941-948. [CrossRef] [PubMed]

5. Sköld, O. Resistance to Trimethoprim and Sulfonamides. Vet. Res. 2001, 32, 261-273. [CrossRef] [PubMed]

6. Huovinen, P.; Sundström, L.; Swedberg, G.; Sköld, O. Trimethoprim and Sulfonamide Resistance. Antimicrob. Agents Chemother. 1995, 39, 279-289. [CrossRef]

7. Matthews, D.; Alden, R.; Bolin, J.; Freer, S.; Hamlin, R.; Xuong, N.; Kraut, J.; Poe, M.; Williams, M.; Hoogsteen, K. Dihydrofolate Reductase: X-Ray Structure of the Binary Complex with Methotrexate. Science 1977, 197, 452-455. [CrossRef] [PubMed]

8. Rajagopalan, P.T.R.; Zhang, Z.; McCourt, L.; Dwyer, M.; Benkovic, S.J.; Hammes, G.G. Interaction of Dihydrofolate Reductase with Methotrexate: Ensemble and Single-Molecule Kinetics. Proc. Natl. Acad. Sci. USA 2002, 99, 13481-13486. [CrossRef]

9. Cammarata, M.; Thyer, R.; Lombardo, M.; Anderson, A.; Wright, D.; Ellington, A.; Brodbelt, J.S. Characterization of Trimethoprim Resistant E. Coli Dihydrofolate Reductase Mutants by Mass Spectrometry and Inhibition by Propargyl-Linked Antifolates. Chem. Sci. 2017, 8, 4062-4072. [CrossRef] [PubMed]

10. Banerjee, D.; Mayer-Kuckuk, P.; Capiaux, G.; Budak-Alpdogan, T.; Gorlick, R.; Bertino, J.R. Novel Aspects of Resistance to Drugs Targeted to Dihydrofolate Reductase and Thymidylate Synthase. Biochim. et Biophys. Acta 2002, 1587, 164-173. [CrossRef]

11. Kuyper, L.F.; Roth, B.; Baccanari, D.P.; Ferone, R.; Beddell, C.R.; Champness, J.N.; Stammers, D.K.; Dann, J.G.; Norrington, F.E.A. Receptor-Based Design of Dihydrofolate Reductase Inhibitors: Comparison of Crystallographically Determined Enzyme Binding with Enzyme Affinity in a Series of Carboxy-Substituted Trimethoprim Analogs. J. Med. Chem. 1985, 28, 303-311. [CrossRef]

12. Singh, A.; Deshpande, N.; Pramanik, N.; Jhunjhunwala, S.; Rangarajan, A.; Atreya, H.S. Optimized Peptide Based Inhibitors Targeting the Dihydrofolate Reductase Pathway in Cancer. Sci. Rep. 2018, 8, 3190. [CrossRef] [PubMed]

13. Galassi, R.; Burini, A.; Ricci, S.; Pellei, M.; Rigobello, M.P.; Citta, A.; Dolmella, A.; Gandin, V.; Marzano, C. Synthesis and Characterization of Azolate Gold(I) Phosphane Complexes as Thioredoxin Reductase Inhibiting Antitumor Agents. Dalton Trans. 2012, 41, 5307-5318. [CrossRef] [PubMed]

14. Gambini, V.; Tilio, M.; Maina, E.W.; Andreani, C.; Bartolacci, C.; Wang, J.; Iezzi, M.; Ferraro, S.; Ramadori, A.T.; Simon, O.C.; et al. In Vitro and in Vivo Studies of Gold(I) Azolate/Phosphane Complexes for the Treatment of Basal like Breast Cancer. Eur. J. Med. Chem. 2018, 155, 418-427. [CrossRef] [PubMed]

15. Galassi, R.; Oumarou, C.S.; Burini, A.; Dolmella, A.; Micozzi, D.; Vincenzetti, S.; Pucciarelli, S. A Study on the Inhibition of Dihydrofolate Reductase (DHFR) from Escherichia Coli by Gold(I) Phosphane Compounds. X-Ray Crystal Structures of (4,5-Dichloro-1H-Imidazolate-1-Yl)-Triphenylphosphane-Gold(I) and (4,5-Dicyano-1H-Imidazolate-1-Yl)-Triphenylphosphane-Gold(I). Dalton Trans. 2015, 44, 3043-3056. [CrossRef] [PubMed]

16. Carlos Lima, J.; Rodriguez, L. Phosphine-Gold(I) Compounds as Anticancer Agents: General Description and Mechanisms of Action. Anti-Cancer Agents Med. Chem. 2011, 11, 921-928. [CrossRef]

17. Gandin, V.; Fernandes, A.P.; Rigobello, M.P.; Dani, B.; Sorrentino, F.; Tisato, F.; Björnstedt, M.; Bindoli, A.; Sturaro, A.; Rella, R.; et al. Cancer Cell Death Induced by Phosphine Gold(I) Compounds Targeting Thioredoxin Reductase. Biochem. Pharmacol. 2009, 79, 90. [CrossRef] 
18. Degan, P.; Carpano, P.; Cercignani, G.; Montagnoli, G. A Fluorescence Study of Substrate and Inhibitor Binding to Bovine Liver Dihydrofolate Reductase. Int. J. Biochem. 1989, 21, 291-295. [CrossRef]

19. Fierke, C.A.; Johnson, K.A.; Benkovic, S.J. Construction and Evaluation of the Kinetic Scheme Associated with Dihydrofolate Reductase from Escherichia Coli. Biochemistry 1987, 26, 4085-4092. [CrossRef]

20. Smith, V.F.; Matthews, C.R. Testing the Role of Chain Connectivity on the Stability and Structure of Dihydrofolate Reductase from E. Coli: Fragment Complementation and Circular Permutation Reveal Stable, Alternatively Folded Forms. Protein Sci. 2001, 10, 116-128. [CrossRef] [PubMed]

21. King, C.; Khan, M.N.I.; Staples, R.J.; Fackler, J.P. Luminescent Mononuclear Gold(I) Phosphines. Inorg. Chem. 1992, 31, 3236-3238. [CrossRef]

22. Hoshino, M.; Uekusa, H.; Ishii, S.; Otsuka, T.; Kaizu, Y.; Ozawa, Y.; Toriumi, K. Polymorphic Crystal Approach to Changing the Emission of $\left[\mathrm{AuCl}\left(\mathrm{PPh}_{3}\right)_{2}\right]$, Analyzed by Direct Observation of the Photoexcited Structures by X-Ray Photocrystallography. Inorg. Chem. 2010, 49, 7257-7265. [CrossRef]

23. Assefa, Z.; McBurnett, B.G.; Staples, R.J.; Fackler, J.P.; Assmann, B.; Angermaier, K.; Schmidbaur, H. Syntheses, Structures, and Spectroscopic Properties of Gold(I) Complexes of 1,3,5-Triaza-7-Phosphaadamantane (TPA). Correlation of the Supramolecular $\mathrm{Au}$......Au Interaction and Photoluminescence for the Species (TPA)AuCl and [(TPA-HCl)AuCl]. Inorg. Chem. 1995, 34, 75-83. [CrossRef]

24. Ziolo, R.F.; Lipton, S.; Dori, Z. The Photoluminescence of Phosphine Complexes of $\mathrm{d}^{10}$ Metals. J. Chem. Soc. D 1970. [CrossRef]

25. Lee, B.; Richards, F.M. The Interpretation of Protein Structures: Estimation of Static Accessibility. J. Mol. Biol. 1971, 55. [CrossRef]

26. Talukder, P.; Chen, S.; Roy, B.; Yakovchuk, P.; Spiering, M.M.; Alam, M.P.; Madathil, M.M.; Bhattacharya, C.; Benkovic, S.J.; Hecht, S.M. Cyanotryptophans as Novel Fluorescent Probes for Studying Protein Conformational Changes and DNA-Protein Interaction. Biochemistry 2015, 54, 7457-7469. [CrossRef]

27. Ohmae, E.; Sasaki, Y.; Gekko, K. Effects of Five-Tryptophan Mutations on Structure, Stability and Function of Escherichia Coli Dihydrofolate Reductase. J. Biochem. 2001, 130, 439-447. [CrossRef]

28. Available online: https://www.sciencedirect.com/topics/neuroscience/dihydrofolate-reductase (accessed on 27 November 2018).

29. Boeri Erba, E.; Petosa, C. The Emerging Role of Native Mass Spectrometry in Characterizing the Structure and Dynamics of Macromolecular Complexes. Protein Sci 2015, 24, 1176-1192. [CrossRef]

30. Yamamoto, T.; Izumi, S.; Gekko, K. Mass Spectrometry on Hydrogen/Deuterium Exchange of Dihydrofolate Reductase: Effects of Ligand Binding. J. Biochem. 2004, 135, 663-671. [CrossRef]

31. Casini, A.; Messori, L. Molecular Mechanisms and Proposed Targets for Selected Anticancer Gold Compounds. Curr. Top Med. Chem. 2011, 11, 2647-2660. [CrossRef]

32. Hashmi, A.S.K.; Rudolph, M. Gold Catalysis in Total Synthesis. Chem. Soc. Rev. 2008, 37, 1766-1775. [CrossRef]

33. Gorin, D.J.; Toste, F.D. Relativistic Effects in Homogeneous Gold Catalysis. Nature 2007, 446, 395-403. [CrossRef]

34. OriginLab-Origin and OriginPro-Data Analysis and Graphing Software. Available online: https://www. originlab.com/ (accessed on 15 March 2019).

35. Weiss, J.N. The Hill Equation Revisited: Uses and Misuses. FASEB J. 1997, 11, 835-841. [CrossRef]

36. Batruch, I.; Javasky, E.; Brown, E.D.; Organ, M.G.; Johnson, P.E. Thermodynamic and NMR Analysis of Inhibitor Binding to Dihydrofolate Reductase. Bioorg. Med. Chem. 2010, 18, 8485-8492. [CrossRef]

(C) 2019 by the authors. Licensee MDPI, Basel, Switzerland. This article is an open access article distributed under the terms and conditions of the Creative Commons Attribution (CC BY) license (http://creativecommons.org/licenses/by/4.0/). 